\title{
Partidos, campanhas e voto: como o eleitor decide nas municipais ${ }^{1}$
}

\author{
Helcimara de Souza Telles \\ Doutora em Ciência Política (Universidade de São Paulo) \\ Professora da Universidade Federal de Minas Gerais \\ Belo Horizonte, Brasil \\ mara-telles@uol.com.br \\ Luiz Cláudio Lourenço \\ Doutor em Ciência Política (Instituto Universitário de Pesquisas do Rio de Janeiro) \\ Professor da Universidade Federal da Bahia \\ Salvador, Brasil \\ luizim@yahoo.com \\ Tiago Prata L. Storni \\ Mestrando em Economia (Centro de Desenvolvimento e Planejamento Regional, UFMG) \\ Belo Horizonte, Brasil \\ tiagoprata@cedeplar.ufmg.br
}

Resumo

\begin{abstract}
A eleição para prefeito na capital mineira em 2008 se deu em contexto complexo, marcado pela alternância dos candidatos nas pesquisas de intenção de voto e pela aliança informal controversa entre PT e PSDB. Este artigo tem o objetivo de apresentar o perfil dos grupos de eleitores e avaliar os determinantes da escolha para prefeito de Belo Horizonte nas eleições de 2008. Usando um modelo de regressão logística multinomial, examinamos, sobretudo, a influência da identidade com os partidos políticos, a avaliação dos desempenhos dos mandatários e da economia e a exposição dos eleitores à campanha sobre a decisão do voto para prefeito. Os dados foram coletados a partir de surveys realizados pela Universidade Federal de Minas Gerais e o Instituto de Pesquisas Sociais, Políticas e Econômicas (Ipespe), no primeiro e segundo turnos da eleição.
\end{abstract}

Palavras-chave: eleições; comportamento eleitoral; identidade partidária; voto.

\section{Comportamento eleitoral e decisão de voto}

$\mathrm{N}_{\mathrm{t}-1}$ A CIÊNCIA POLÍTICA, uma das preocupações mais antigas e centrais é verificar como o eleitor se comporta diante das urnas. Esse problema de pesquisa gerou diversas teorias que, com o passar do tempo, foram agrupadas nas chamadas escolas de comportamento eleitoral. Dentre as principais correntes, destacam-se e são apontadas recorrentemente pela literatura a sociologia eleitoral (ou sociologia política), a perspectiva psicológica (ou Escola de Michigan) e a escolha racional. Para cada uma dessas escolas e de suas respectivas teorias, uma gama

1 Este artigo apresenta resultados parciais da pesquisa Opinião pública: partidos políticos e comportamento eleitoral, financiada pela Fundação de Amparo à Pesquisa do Estado de Minas Gerais (Fapemig) e pela Pró-Reitoria de Pesquisa (PRPq) da UFMG. Os dados fazem parte do subprojeto "A decisão de voto em eleições municipais", realizado através de termo 
distinta de fatores se torna fundamental para a explicação do voto.

$\mathrm{Na}$ sociologia eleitoral (Lazarsfeld, Paul; Berelson, Bernard; Guadet, Hazel, 1948), também conhecida como sociologia política, os fatores explicativos do voto dizem respeito ao contexto social e interpessoal, nos quais os indivíduos estão inseridos, mais do que apenas às campanhas eleitorais e aos conteúdos da mídia que, nos estudos iniciais, eram visto como únicos causadores da opinião pública. Em uma interconexão com a análise histórico-estrutural, a sociologia eleitoral busca conhecer a incidência dos processos socioeconômicos e culturais na conduta política dos indivíduos. O principal pressuposto é o de que eleitores com condições socioeconômicas semelhantes tendem a um comportamento político também similar, uma vez que as condutas políticas derivam de posições estruturais ou dos chamados 'coletivos sociais'.

Segundo esse modelo, as campanhas políticas têm uma influência direta relativamente pequena na elaboração e na transformação das decisões eleitorais, pois a exposição aos meios de comunicação seria filtrada pelos interesses e esses interesses, por sua vez, dependeriam da inserção do indivíduo na sociedade - seu status socioeconômico, escolaridade, sexo etc. Assim, a influência dos meios de comunicação estaria condicionada pelos interesses dos grupos, pelas identidades de classe e por sua posição social, definida por sua renda e escolaridade. Algo importante para ressaltar aqui é o papel da interação entre os indivíduos (two-step flow ou teoria do fluxo comunicacional em duas etapas), que daria legitimidade ou não aos discursos veiculados nos meios de comunicação. Assim, as campanhas teriam uma influência mediada por essa validação social.

A preocupação da sociologia eleitoral era menos a de mensurar a influência da mídia e mais a de verificar os possíveis padrões de relacionamento entre o eleitor e os meios de comunicação. Na medida em que os eleitores ficassem expostos aos meios de comunicação, o seu interesse pela política seria aumentado, mas as suas posições não seriam necessariamente convertidas. Nesse sentido, resulta o chamado efeito de ativação e efeito de reforço, o que significa que a exposição às campanhas desperta o interesse e reforça as convicções já presentes nos grupos e os leva a rechaçar as informações que contrariam tais interesses. Mais do que converter eleitores ou dar insumos para formar a opinião desses votantes, as campanhas teriam efeitos diretos limitados. A sociologia política apresentou uma importante inovação, ao tratar o eleitor como um sujeito ativo: a capacidade da mídia e da propaganda nela veiculada para manipular as opiniões, comumente aceitas até então, não encontrou eco nesse modelo, que apresenta um eleitor ativo diante dos discursos midiáticos.

A corrente psicológica, criada a partir da década de 1950 pela Escola de Michigan, refuta a hipótese adotada pela sociologia. O comportamento eleitoral passa a ser estudado segundo disposições individuais e não apenas coletivas. A escola psicológica e a psicossociológica acreditam que as atitudes, a percepção e as crenças dos eleitores sobre política seriam intervenientes importantes para explicar a decisão dos votantes. A unidade de análise dessas teorias é o indivíduo e não um grupo ou classe social. Assim, os fatores estruturais e de caráter mais coletivo - conforme apresentados pelo modelo sociológico - não seriam suficientes para explicar o comportamento eleitoral. A estrutura de crenças e as opiniões sobre política seriam constituídas no próprio processo de formação social dos indivíduos. $\mathrm{O}$ trabalho mais representativo dessa linha se encontra em The American voter (1960), de Angus Campbell, Philip Converse, Warren Miller e Donald Stockes, no qual se interpretam os indivíduos e suas motivações psicológicas. A diferença entre a corrente psicossociológica para a psicológica é a de que a primeira agrega também fatores que dizem respeito ao grupo social a que o indivíduo pertence.

Dentre as conclusões dessa corrente está a de que a maioria dos eleitores tende a expressar os seus votos baseando-se na identidade partidária, sendo que tal identidade pode ser herdada da família ou na socialização. Os valores adquiridos no processo de socialização podem ser relevantes para as decisões políticas, o que significa que o voto será orientado ao partido que melhor represente esses valores. Essa corrente não reconhece a ideologia como um componente predominante na decisão eleitoral e indica em seu lugar o conceito de "identificação partidária", que não está relacionada necessariamente com conteúdos ideológicos (Campbell et al., 1960).

Observa-se que a Escola de Michigan desconsiderou os efeitos da campanha e da mídia na decisão de voto. Em primeiro lugar, porque supõe que a maioria dos eleitores não se interessa pela política; em segundo lugar, os cidadãos ativos, que são minoria, e que acompanham a imprensa, têm identidade com partidos e agem motivados por tal identificação. Assim, o contato frequente dos indivíduos ativos com a mídia, mais do que realizar

de cooperação entre a UFMG e o Instituto de Pesquisa Sociais, Políticas e Econômicas (Ipespe). Uma versão deste artigo foi apresentada no II Congreso Latinoamericano de Opinión Pública (Lima, Peru, abril de 2009), promovido pelo World Association of Public Opinion Research (Wapor). Agradecemos aos inúmeros estudantes do Grupo de Pesquisa da UFMG - Opinião Pública, Marketing Político e Comportamento Eleitoral, que auxiliaram em várias etapas dos surveys com os eleitores de Belo Horizonte. Somos também gratos pelas sugestões feitas pela equipe técnica do Ipespe, especialmente a Antonio Lavareda, que não mediu esforços para a viabilização desta pesquisa. Naturalmente, os erros que porventura existam são de nossa inteira responsabilidade. Uma primeira versão foi apresentada no II Congreso Latinoamericano de Opinión Pública del Wapor (abril de 2009). Contudo, utilizamos bases respondentes um pouco distintas para a variável "avaliação do HGPE". 
a conversão do voto, estabelece o mesmo efeito encontrado pela sociologia política, qual seja, o de reforçar a identidade com o partido previamente selecionado.

A perspectiva da "escolha racional" se diferencia dessas outras correntes porque, segundo esta, o elemento principal é o incentivo econômico compensatório. O precursor dessa teoria, Anthony Downs (1957), assimilou o comportamento racional do eleitor ao do consumidor no mercado. A escolha racional e as teorias econômicas do voto podem ser agrupadas conjuntamente, uma vez que trabalham com a ideia de um cálculo racional executado pelo eleitor para decidir seu voto. Esse cálculo é feito a partir da avaliação da economia. Assim, se a economia vai bem, o campo político da situação é favorecido; por outro lado, se a economia vai mal, a oposição é beneficiada. Para Downs, a identificação partidária e o comportamento eleitoral seriam derivados da expectativa de maximização de utilidade por parte do eleitor. A identificação ideológico-partidária seria um atalho informacional adotado pelo eleitor justamente para diminuir as incertezas de sua escolha nas urnas. E deve ser ressaltado que a identidade partidária tem como referência a ideologia.

Do ponto de vista da escolha racional (rational choi$c e$ ), o cálculo eleitoral é feito a partir da satisfação com relação aos benefícios que o indivíduo julga ter no caso de vitória de um dos candidatos, seja este da oposição ou da situação. Por isso, os votantes necessitam deter informação - que funciona como um redutor das incertezas e balizador para a tomada de decisões. Por isso, diferentemente das correntes anteriores, a escolha racional atribui significado para as campanhas políticas e para os meios de comunicação, pois esses canais são importantes fontes de informação e de divulgação de ideias, utilizadas pelo eleitor para balizar suas decisões.

Nas teorias sobre o comportamento eleitoral, houve em geral um relativo descaso com o papel exercido pelo conteúdo da mídia e pelas campanhas políticas. Tanto a Escola de Michigan quanto o modelo sociológico relegaram um papel secundário às campanhas na decisão do votante. A escola sociológica desmistifica o papel onipotente dos conteúdos da mídia, mas não avança muito na análise da importância que tem uma campanha a partir da validação social de seu discurso.

Nas últimas duas décadas, as campanhas eleitorais ressurgiram a partir de novos estudos como um argumento a ser levado em conta no debate sobre a explicação do comportamento do eleitor (Holbrook, 1996; Iyengar e Simon, 2000; Mancini e Swanson, 1996;
Riker, 1996). A maneira de fazer política se modificou sobremaneira nesse período, redimensionando os papéis de vários atores nas democracias ocidentais, inclusive dos meios de comunicação e das campanhas eleitorais neles veiculadas. Uma das constatações mais expressivas nessa nova configuração, chamada por Bernard Manin (1995) como "democracia de público", foi a de que houve uma grande diminuição dos eleitores que afirmam ter uma identificação partidária. Essa tendência de declínio dos índices de participação em organizações partidárias e de pouca identificação com partidos políticos, em muitos países, também foi observada por diversos estudos (Mainwaring, 1999; Dalton, 2000; Dalton, McAllister e Wattenberg, 2000). Por outro lado, é cada vez mais expressiva a parcela do eleitorado que passa a pensar sobre política e fazer sua decisão a partir do início das campanhas eleitorais nos meios de comunicação, quando é iniciado o "tempo da política"2 (Palmeira, 1992; Palmeira e Heredia, 1993).

Em função dessas novas configurações, as variáveis conjunturais, ou de curto prazo, podem auxiliar na explicação do voto em sociedades que produzem resultados eleitorais mais instáveis, como pode ser observado, sobretudo, nas sociedades latino-americanas. Nessas sociedades, em que a democracia muitas vezes ainda se encontra em processo de consolidação e os partidos não são instituições fortemente institucionalizadas, é notável a desconfiança dos eleitores nas organizações formais de representação política, tanto os partidos isoladamente, como também as casas de representação política (câmaras de deputados, senados etc.). Em grande parte dos países latino-americanos, os índices de desconfiança são maiores para com as instituições políticas do que para com a imprensa e os meios de comunicação. ${ }^{3}$ Soma-se a isso a baixa identidade partidária e alta volatilidade eleitoral, e podemos compreender como aumenta a importância das campanhas televisivas nas estratégias dos partidos.

Dentro desse cenário, muitos pressupostos teóricos começaram a ser repensados. Afinal, os parâmetros para uma escolha que expressasse racionalidade por parte do eleitor, definidos por Arrow (1951) e Downs (1957), passaram a não ser observáveis. Mas isso significaria que o eleitor é irracional? Neuman (1986) descreveu o eleitor médio americano como desinteressado, com pouca informação sobre política, sem opinião sobre assuntos políticos, com baixa estruturação do pensamento político, entre outras características que

2 O chamado "tempo da política" aqui é a designação dada a partir da percepção de eleitores de quando a política é realizada, o que corresponde ao período eleitoral no qual as campanhas são veiculadas e inicia-se a persuasão em busca de votos por parte dos candidatos em todos os níveis.

3 Informe Latinobarómetro de 2008 indicou que somente $20 \%$ dos brasileiros têm muita ou alguma confiança nos partidos políticos e $34 \%$ no Congresso Nacional, enquanto $60 \%$ e $62 \%$ confiam muito ou algo na TV e nos jornais, respectivamente. Esses valores foram próximos à média latino-americana. Em Belo Horizonte, a nota média da confiança nos partidos foi de 3,5; na imprensa 5,1 e na Igreja 6,2, em uma escala de 0 a 10, de acordo com dados da pesquisa "A decisão de voto em eleições municipais", do Ipespe/UFMG. 
o desqualificam como o eleitor tipicamente racional de Downs. Mas se o eleitor médio é tão pouco capaz, como as democracias funcionam relativamente bem? Como eleitores "ruins" fazem "boas" democracias?

Lupia e McCubbins (1998) produzem uma resposta muito interessante para essa questão. $O$ primeiro passo dado foi o de formular de maneira muito clara e precisa o que podemos entender como uma escolha feita racionalmente. Escolhas racionais, para eles, são tomadas "sempre que as pessoas podem prever de forma clara as consequências de suas ações" (Lupia e McCubbins, 1998, p. 18). Os autores sustentam que não precisamos saber tudo ou ter informação plena para tomar uma decisão racional; no dia a dia tomamos decisões a partir de alguns fragmentos de informação. Isso é feito através de um processo denominado de "conectismo" ou "coneccionismo" (connectionism). Esse é um meio que permite às pessoas conectarem suas observações cotidianas, presentes em seu mundo físico, a experiências e feedback físicos e emocionais (Lupia e McCubbins, 1998, p. 19), fornecendo assim mais subsídios para suas escolhas.

A maioria das informações usadas pelos eleitores para votar é adquirida como um produto (by-produt) de atividades que eles perseguem como parte de suas vidas cotidianas. Além disso, os eleitores superariam suas limitações de informação através de atalhos (shortcuts) que incorporariam experiências passadas, a vida cotidiana, a mídia e as campanhas políticas (Popkin, 1994). Popkin identifica, então, três tipos básicos de operações pelos quais os eleitores fariam uso desses atalhos: 1) avaliando; 2) obtendo, e 3) guardando informações (1994, p. 44).

Um dos trabalhos que mais se preocupou com as avaliações feitas pelo eleitor é de Moris Fiorina (1981). Essas avaliações são contextuais e dizem respeito, sobretudo, à atuação do governo, portanto são retrospectivas. A influência do cálculo retrospectivo iria para além da definição do voto em apenas uma eleição e poderia também imprimir, reforçar ou modificar a imagem de um partido ou de um candidato. Embora o trabalho de Fiorina não esteja preocupado com a campanha eleitoral, sabemos que através das campa- nhas o eleitor soma elementos de informações para fazer qualquer tipo de avaliação do partido ou do candidato que está ou quer entrar no governo.

No Brasil, a tradição de estudos eleitorais foi acentuada na década de 1970, destacando-se a coletânea de Lamounier e Cardoso, Os partidos e as eleições no Brasil; de Fábio Wanderley Reis, Os partidos e o regime: a lógica do processo eleitoral brasileiro; e o livro de Bolívar Lamounier, Voto de desconfiança: eleições e mudanças politicas no Brasil 1970-1979. Em grande parte destes estudos, a identificação com os partidos emerge como um importante elemento explicativo para o comportamento do eleitor, como no caso do MDB, percebido pelo eleitorado como partido popular, ao contrário da Arena, vista como agremiação dos ricos. ${ }^{4}$ Do ponto de vista da compreensão mais geral sobre a decisão de voto no Brasil, encontra-se o livro de Figueiredo (1991), que debate, sobretudo, a racionalidade no processo decisório.

$\mathrm{Na}$ literatura atual, as eleições presidenciais se constituem como o principal foco para a análise do comportamento do eleitor (Lourenço, 2006; Venturi, 2006; Carreirão; 2002; Almeida, 2001; Singer; 2000; Silveira, 1998; Castro, 1994). ${ }^{5}$ Entretanto, escassas pesquisas se debruçam sobre a lógica do eleitor nas municipais. Pode-se assumir que o local e o nacional não sejam esferas independentes. Porém, o comportamento político seria mais inteligível caso fossem aprofundados os sentidos dessas conexões. Essas articulações não nos parecem sejam simples e banais; a presunção da existência de semelhantes padrões de comportamento, segundo a qual a lógica para as presidenciais corresponderia ao mesmo arquétipo da decisão nas municipais ou nas legislativas, exige maior tratamento e testes empíricos. ${ }^{6}$

Os estudos mais recentes sobre o comportamento do eleitor não atingem um consenso a respeito da estruturação ideológica e da identidade com os partidos como preditoras do voto. A ideologia foi examinada por Singer (2000), que apresentou uma definição mais flexível do que a concepção presente na Escola de Michigan. Singer trata o conceito de ideologia a partir da combinação entre o voto por imagem (Sartori, 1982)

4 Esses partidos existiram no Brasil durante o período da ditadura militar e desapareceram depois do processo de redemocratização, quando foram autorizadas outras agremiações.

5 Kinzo e Braga (2007) organizaram uma coletânea que analisa não somente a dinâmica das eleições nacionais, o que constitui um importante esforço para entender o comportamento do eleitor no plano legislativo e municipal.

6 Embora se possa contra-argumentar que não há sentido em se compreender o eleitor como se este dispusesse de racionalidades distintas para cada esfera de eleição, pode-se ponderar, por outro lado, que as motivações para o voto podem variar dependendo desses planos, sem que tal variação seja resultante de uma conduta não racional. Uma questão que nos parece pouco debatida é a de saber se o eleitor utilizaria padrões diferenciados para votar em cada uma dessas esferas, seja porque a sua identidade é suficientemente intensa para um nível, mas não faça sentido em outro, seja porque questões conjunturais possam ser mais consideradas para o cálculo do voto em uma esfera que em outra; ou simplesmente porque, apesar da sofisticação, ideologia ou racionalidade, o eleitor teria motivações justificadas para ser levado a utilizar distintas informações para se decidir em cada um dos níveis das eleições: local, estadual e nacional. Trata-se, portanto de, antes de atribuir irracionalidade a uma conduta, explorar esse eleitor comum, que se prepara para votar no prefeito de sua cidade, carregando para a urna a sua a família e amigos, as suas identidades, uma cultura política ou informações adquiridas na mídia ou em outras fontes às quais ele atribui crédito. 
e o sentimento ideológico (Levitin e Miller, 1979). Para tanto, Singer mensura o conceito a partir da autolocalização do eleitor na escala esquerda-direita. Após suas conclusões, o debate sobre o tema foi reacendido, no sentido de verificar a capacidade preditora dessa variável sobre o voto (Carreirão 2002; 2007; Almeida, 2001). Em que pesem as divergências, muitos concordam quanto ao baixo grau de informação e ao caráter pouco estruturado e difuso das opiniões políticas da maioria dos eleitores e, em segundo lugar, com o fato de a decisão de voto estar "fortemente estruturada pelas 'imagens políticas' e avaliações que o eleitor faz de algumas características pessoais dos candidatos em disputa" (Borba, 2005, p. 161).

A interação entre as campanhas e o eleitor modifica expressivamente os índices de intenções de voto (Thomas Holbrook, 1996). As campanhas podem ser vistas como um conjunto de atividades de intervenção realizadas com a intenção de aumentar os votos e vencer uma eleição. Mas também são fóruns para a deliberação política e instituições discursivas. Por isso, é importante frisar que o interesse recente no estudo de campanhas políticas e eleições no Brasil não é restrito apenas à área da Ciência Política, mas, além disso, da comunicação (Rubim, 2000; Lima, 2001) e da antropologia (Kuschnir, 2000; Palmeira, 1996). A interdisciplinaridade no trato do tema fez com que houvesse uma melhor compreensão dos fenômenos de campanha no país e do que essas poderiam representar dentro de uma eleição e na decisão do voto no Brasil.

Os trabalhos mais recentes sobre comportamento eleitoral no Brasil tiveram pouca preocupação em verificar a importância das avaliações feitas pelos eleitores do Horário Gratuito de Propaganda Eleitoral (HGPE) dos candidatos. Contudo, significaram avanços: primeiro na elaboração de modelos econométricos de caráter mais preciso e com maior elaboração técnica, além de incorporar bases de dados confiáveis e variáveis de avaliação de governo. Contudo, como já foi dito, esses modelos não incorporaram aspectos relativos às campanhas (Carreirão, 2002 e 2007; Nicolau, 2007). Combinando tanto técnicas de pesqui- sas qualitativas quanto modelos estatísticos (a partir de um experimento), Lourenço (2007) demonstra que a avaliação dos programas do HGPE pode afetar as chances (maiores ou menores) de voto em determinado candidato, nas eleições presidenciais de $2002{ }^{7}$

\section{I.1. O problema e o foco de análise: as lógicas do voto para prefeito}

Nas grandes cidades e capitais brasileiras, as eleições e as campanhas eleitorais são realizadas mesclando as práticas políticas mais tradicionais ao uso das mais sofisticadas técnicas de linguagens televisivas e o emprego da televisão tem adquirido centralidade. Na propaganda eleitoral, a ausência do nome da coligação ou de todos os partidos que compõem a aliança, a falta do nome do vice dos candidatos majoritários são problemas frequentemente encontrados. $\mathrm{O}$ partido, se não totalmente excluído, na maior parte, surge como um adereço sem maior importância no material de campanha. ${ }^{8}$ E o eleitor, como reage em contextos nos quais as eleições são disputadas em campanhas que têm acentuado o uso de nomes de lideranças em detrimento do partido e otimizado a televisão como principal fonte de informação sobre a política? O eleitor se comporta no plano das eleições municipais selecionando as mesmas informações que utiliza para votar no presidente?

A literatura apresenta estudos de casos não apenas para a América Latina, mas para diversos países, em que se segue o declínio do voto partidário e o crescimento do voto não ideológico e muitas vezes baseado em padrões de interação clientelista entre os eleitores e os candidatos. Assim, vale a pena indagar se as identidades com os partidos - conforme proposto pela Escola de Michigan e pela escolha racional - e a natureza e densidade da identidade política entre eleitores e candidatos/ partidos, segundo esperado pela teoria sociológica, ainda conduzem a decisão de voto. Cabe ainda avaliar se o voto retrospectivo, baseado na avaliação do desempenho dos partidos e seus representantes, faz algum sentido nesses contextos marcados por uma suposta erosão nas identidades com classes e partidos.

$7 \mathrm{Na}$ agenda desses estudos, está presente os efeitos das campanhas televisivas sobre a direção do voto e a criação de uma agenda política (Oliveira, 2007; Lourenço, 2007; Rubim, 2006; Dias, 2005; Oliveira, 2004; Figueiredo et al, 2000; Albuquerque, 1999). A análise da retórica utilizada nos programas do Horário Gratuito de Propaganda Eleitoral (HPGE) e dos spots eleitorais através de uma metodologia de estudo que pudesse observar como se dispunham e qual a magnitude veiculada desses elementos persuasivos foi um passo importante no estudo das campanhas televisivas (Albuquerque, 1996; Figueiredo et al., 1998; Jorge, 1995; Lourenço, 2000; Silva, 2000). No que diz respeito às análises da retórica, Oliveira (2007) trata de avaliar comparativamente as campanhas para prefeito do Rio de Janeiro e de São Paulo (1992 e 1996), apreciando os conteúdos dos discursos enunciados pelos candidatos e pela mídia, na construção de candidatos; Telles (2009), orientando-se pelas categorias analíticas de Figueiredo et al (2000), interpreta as mensagens políticas veiculadas nos spots e nos programas eleitorais das campanhas da cidade de Salvador para, a partir disso, fazer inferências a respeito das representações ideológicas, valorativas e as expectativas acerca do comportamento do eleitor, contidas nos slogans de campanha. E, finalmente, Rocha Neto (2008) realiza um estudo inédito acerca da profissionalização das campanhas eleitorais no Brasil, propondo um índice para mensurar tal profissionalização das campanhas nos principais partidos brasileiros.

8 Contudo, a medição do impacto das propagandas gratuitas, das campanhas eleitorais e de seus eventos sobre a decisão do voto ainda é mais debatida que analisada; apesar dos avanços nessa área, ainda são reduzidos os trabalhos que incorporam fatores presentes nas campanhas como explicativos do voto em seus modelos de análise e o uso de metodologias mais sofisticadas para a análise dos votos está circunscrito às presidenciais. 
O objetivo do artigo é o de realizar um esforço para cotejar algumas explicações propostas pela Ciência Política para o comportamento eleitoral, identificando fatores explicativos para o voto, retiradas das teorias apresentadas, sobretudo a teoria sociológica, que enfatiza os determinantes macroprocessuais e de longo prazo, e as proposições que repousam sobre os fatores de tipo micro, como a identidade partidária; além de apresentar as variáveis de curto prazo - como as campanhas políticas. Os dados que serão analisados foram coletados no primeiro e segundo turnos das eleições para prefeito em 2008 na cidade de Belo Horizonte. A constituição de modelos econométricos a partir de surveys para verificar a magnitude da relação entre a avaliação e a exposição à campanha e o voto constituem um dos esforços aqui almejados.

\section{II - As eleições e a campanha para prefeito de Belo Horizonte}

\section{II.1.As estratégias de campanha: o personalismo e o continuísmo}

Em 2008, a cidade de Belo Horizonte, governada pelo prefeito Fernando Pimentel (PT), passou por uma eleição atípica em sua história política. O empenho de grupos petistas locais na construção de uma aliança formal entre o PSDB e o PT, o elevado número de indecisos, as significativas mudanças observadas nas preferências dos eleitores durante todo o processo eleitoral e os ataques pessoais deram a essa eleição um caráter diferenciado das demais. Isso fez com que os prognósticos em relação aos resultados para prefeito se tornassem imprevisíveis, durante todo o processo.

As eleições permitiram que a aliança de centroesquerda, entre PSB e PT, persistisse no governo da cidade. A chapa liderada por Márcio Lacerda (PSB) conseguiu vencer no segundo turno, com $59,1 \%$ dos votos, derrotando o deputado federal Leonardo Quintão, do PMDB. Tal resultado apenas confirmou uma situação que se apresentou desde 1992 quando, pela primeira vez, o PT administrou a capital mineira. Além de conseguir manter-se na administração, indicando o vice na chapa do PSB, o PT municipal, ao amparar a candidatura de Márcio Lacerda, impôs uma derrota ao grupo comandado pelo ex-prefeito Patrus Ananias (PT). O candidato Lacerda contava com muitas restrições por parte tanto de lideranças petistas nacionais quanto dos segmentos locais reunidos em torno do ministro Patrus Ananias. A principal restrição ao seu nome era derivada do fato de ter ativa participação como secretário estadual na gestão de Aécio Neves, governador de Minas pelo PSDB.

O período da pré-campanha foi marcado pela liderança precoce da candidata comunista Jô Moraes (PC do B) nas pesquisas e pela discussão dessa aliança entre o PSDB e PT, coalizão enunciada pelo grupo do então prefeito Fernando Pimentel (PT). ${ }^{9}$ Após exaustivos debates, a Executiva Nacional do PT rejeitou a coligação com o PSDB, resultado que teve de ser acatado pelo PT municipal. Todavia, apesar desse veto, a máquina do governador foi mobilizada para a campanha do candidato Márcio Lacerda, lançado como cabeça-de-chapa e tendo como seu vice o deputado estadual Roberto Carvalho, experiente parlamentar do PT e apoiador inconteste da proposta da "aliança".

Os articuladores da "Aliança por BH" esperavam contar com adesão popular imediata, tendo em vista que os principais concorrentes não manejavam máquinas partidárias poderosas. Tanto o PMDB quanto o PC do B tinham na ocasião pouca representatividade na Câmara Municipal e não conseguiram se articular com outras forças significativas para participar da disputa. Mas os patronos da união PT/PSDB baseavam-se sobretudo em pesquisas de cenários eleitorais anteriores, que apresentavam a ótima avaliação e a satisfação do eleitor de $\mathrm{BH}$ com a administração tucana, no governo estadual, e com a petista, no município. Dessa situação, as lideranças petistas municipais e "aecistas" inferiram que tal desempenho positivo seria facilmente transferido para votos no candidato por eles apoiado e que a eleição seria, portanto, definida já no primeiro turno. A aposta de uma vitória fácil ainda no primeiro turno foi sustentada pela expectativa de que o eleitor votaria no candidato que representasse a continuação dessas políticas, portanto o voto seria retrospectivo-personalista.

A confiança no voto pelo continuísmo seria fortalecida caso o candidato Lacerda dispusesse de experiência política no Executivo, o que não ocorria. $\mathrm{O}$ problema de ser um candidato com reduzida inserção política seria compensado com a valorização do atributo funcional da sua competência técnica Além disso, para equilibrar essa falta de experiência, Lacerda deveria ser associado como continuador dos governos estadual e municipal, e o governador Aécio e o prefeito Pimentel seriam os garantidores do futuro. Em função da avaliação positiva desses governos, o apoio de Aécio foi acirradamente disputado por Leonardo Quintão, candidato pelo PMDB. 
A estratégia de campanha da "Aliança por BH" desdobrou-se na preferência pelo uso da televisão e do programa do Horário Gratuito de Propaganda Eleitoral Gratuito (HGPE). Na estratégia retórica, seria agora "a hora e a vez" de Minas restaurar o comando político do país. Tal recuperação seria obtida com o fim das diferenciações entre os partidos e a reunião dos bons políticos em torno de um projeto nacional. A mineiridade - a suposta capacidade de Minas para propor situações de entendimento, recorrentemente utilizada por Tancredo Neves na disputa pelo governo estadual de 1982 - foi um dos focos recorrentes. Assim, a campanha primou pela centralidade do pacto social e de um projeto mineiro de conciliação entre os partidos. O slogan "Meu partido é BH", selecionado como síntese desse discurso político, expressa o tom conciliatório e apartidário que foi modulado pela propaganda da "Aliança" na capital mineira.

A candidatura de Leonardo Quintão (PMDB) foi forjada no personalismo e na emoção. Parlamentar jovem, era considerado como o mais simpático entre os candidatos, segundo opinião do eleitorado aferida pelos surveys realizados. Quintão buscou se diferenciar de Lacerda - que era um nome técnico, sem expressão e apelo popular, falava pouco e era tímido diante das câmeras e fora delas -, empregando um tom emotivo na sua propaganda eleitoral televisa e adotou o slogan "é gente cuidando de gente". Além do uso da imagem na televisão e dos programas de rádio ao estilo Osvaldo Betio, em que utilizava uma fala mansa e simples, com forte sotaque mineiro, o staff da campanha aderiu às técnicas tradicionais da campanha de rua, apresentando-o como o candidato popular, ao contrário de Lacerda, associado a um produto dos bastidores e das modernas técnicas de marketing. Essas táticas do candidato do PMDB, conjuntamente empregadas, além de um bom desempenho em debates, podem ter garantido votos para Quintão.

Os discursos enunciados pelas campanhas estabelecem o diálogo com o público e com os demais atores e as retóricas são reconstruídas na interação e no conflito. Lacerda pretendia representar a situação, mas o papel de opositor nesse jogo não foi aceito por Leonardo Quintão, candidato pelo PMDB. Uma condição importante apontada pela literatura, para a decisão de voto, seria a distinção entre os candidatos, com o sentido de diferenciá-los e assim ativar a participação e o interesse pela política. No modelo dowsiano, essa diferenciação seria dada sobretudo pelo posicionamento como "situação" e "oposição", que são posições importantes para orientar a decisão de voto. Ao diferenciar os candidatos, esses eixos permitem que o eleitor possa usar essa informação para calcular sobre as suas vantagens em caso da vitória de um desses. Todavia, Leonardo Quintão optou pela retórica de mandatário. Rejeitou o atributo de oposi- cionista, apresentando-se como o melhor continuísta do modelo da política municipal, e denunciava o caráter arbitrário da escolha de Lacerda.

Essa escolha estratégica do PMDB resultou em que o mundo presente foi construído como bom, ou pelo menos não foi frontalmente desconstruído, por ambas as candidaturas. Portanto, tratava-se de disputar a agenda de quem seria o melhor garantidor do futuro. Por isso, em que pese a associação entre o governador Aécio e o candidato Lacerda na campanha da "Aliança", também Quintão trouxe o governador e o presidente Lula, dos quais se declarava um admirador, para o interior de sua campanha. $\mathrm{O}$ apoio dos mandatários estaduais e nacionais afiançaria que, qualquer que fosse o eleito, ambos disporiam de condições políticas adequadas para governar, o que os colocava em posição de igualdade, em termos da oferta de segurança para o futuro gestor.

Não se sabe como essas retóricas foram lidas pelo público. Mas a percepção do eleitor sobre as duas candidaturas caracteriza-as de modos distintos, podendo-se observar como essas imagens projetadas pelas campanhas foram acolhidas pelo eleitorado. Quando convidados a relacionar os candidatos com um conjunto de afirmativas, os perfis emergem como uma interação entre os discursos enunciados. No primeiro turno, Márcio Lacerda foi relacionado como o candidato com o melhor partido (46,5\%); localizado à direita $(33,5 \%)$; o que mais defende os mais ricos $(32,8 \%)$. Mas também era avaliado como o melhor para o futuro de Belo Horizonte (48\%); o que tinha o apoio mais importante $(80 \%)$, e o candidato com mais chances de vencer as eleições (72\%). Já no segundo turno, foi o mais relacionado com a frase "rouba, mas faz" e novamente associado ao defensor dos mais ricos (41\%). Leonardo Quintão, no primeiro turno, destaca-se, com Jô Moraes, por ser o mais preocupado com os mais pobres (16\%); no segundo turno, por ser o mais simpático $(50 \%)$ e o mais corajoso (42\%); novamente o mais preocupado com os pobres (40\%), mas também como o candidato que mais mente (36\%). ${ }^{10}$

Ademais do apartidarismo encontrado nas campanhas dessas duas candidaturas no primeiro turno, as eleições tiveram em geral um caráter federalizado, ainda que isto não fosse explicitamente declarado. Circulava livremente na imprensa e nos debates a ideia de que, do resultado desta eleição, sairia a definição dos presidenciáveis em 2010, pelo PSDB. A vitória do candidato a prefeito apoiado pelo governador Aécio Neves com adesão de petistas poderia credenciar o governador mineiro como um forte pretendente a presidente em 2010, no duro embate que teria pela frente com o paulista José Serra (PSDB), também candidato declarado. Minas e São Paulo seriam dois projetos distintos de poder. Enquanto São Paulo representava o 
conflito e a elevação dos interesses particularistas desse estado para a esfera nacional, a solução Aécio-PT apontava para a construção de um projeto nacional e de promoção dos interesses públicos sobre os interesses dos estados e de suas facções. A própria construção da aliança era nada mais que o acordo entre as lideranças estaduais e municipais em torno desse projeto, que não se finalizava no âmbito do município.

A ausência de oposição declarada aos governos e a desaparição dos partidos políticos nos discursos de campanha, sobretudo no primeiro turno, associados à falta de experiência dos concorrentes em cargos executivos, tornam esta eleição muito mais complexa do que supõe o esquema clássico, em que o jogo retórico e as decisões dos votantes são elaborados a partir do eixo "oposição e situação". Na ausência dessas informações, o eleitor tem de buscar outros subsídios e atalhos para decidir-se nas urnas. A expectativa de uma vitória fácil no primeiro turno, como esperado pela "Aliança", rapidamente desvaneceu e o quadro ficou bastante intricado, pois não se tratava de reeleição, em que chefes do Executivo, quando bem avaliados, têm probabilidades maiores de se reeleger, como demonstram os últimos resultados eleitorais no Brasil.

O fato é que a associação de Lacerda com os seus padrinhos políticos não resultou na avalanche de votos esperados, e a eleição foi decidida no segundo turno. O eleitor mostrou-se surpreendentemente volátil, pois as preferências variaram enormemente. A acirrada disputa pelo apoio do governador e a situação de empate técnico com que terminou o primeiro turno resultaram em mudanças significativas nas campanhas. A campanha light terminou tão logo os resultados da primeira rodada foram divulgados. Os ataques, as denúncias políticas e a desconstrução de imagens dos concorrentes passaram a ser a tônica da segunda rodada. ${ }^{11} \mathrm{O}$ personalismo foi abrandado e os partidos emergiram na campanha. O capital político construído pelo PT ao longo das administrações municipal e federal foi disputado. Quintão tentou se apresentar como o continuador da obra de Patrus Ananias, primeiro petista prefeito da cidade, e Lacerda acoplouse aos movimentos sociais, apresentando o apoio de sindicalistas e lideranças populares. Na retórica da "Aliança", Lacerda representava os setores progressistas e Leonardo Quintão, o atraso e o populismo.

O principal jornal local - O Estado de Minas passou a apoiar abertamente a campanha de Márcio Lacerda e disseminava as informações negativas pro- duzidas pela campanha da "Aliança por BH". Mas lideranças locais do PT ficaram divididas entre Lacerda, Quintão e a neutralidade, o que tornou o segundo turno ainda mais complexo e incerto.

\section{II.2. O histórico dos números: volatilidade nas intenções de voto e indecisão}

A análise do histórico das intenções de votos revela que, em curto espaço de tempo, os candidatos alternavam de posição. Durante o segundo turno, em um período curto, Leonardo Quintão chegou a ganhar a confiança de $47 \%$ dos eleitores, para em seguida perder voto de seus eleitores; Márcio Lacerda, que no período inicial do segundo turno perdeu votos, voltou a crescer. A evolução das preferências pode ser observada com mais detalhes no gráfico 1.

Para a análise desses números, importa ressaltar antes que a "Aliança" reuniu em torno de si doze parceiros, representantes dos mais diferentes espectros ideológicos, inclusive da direita - PSB/PT/PTB/ $\mathrm{PP} / \mathrm{PR} / \mathrm{PV} / \mathrm{PMN} / \mathrm{PSC} / \mathrm{PSL} / \mathrm{PTN} / \mathrm{PTC} / \mathrm{PRP}-$, o que levou essa coligação a dispor do maior tempo de propaganda na televisão: 11 minutos e 47 segundos diários ou $41 \%$ do tempo total destinado aos partidos. Leonardo Quintão (Belo Horizonte Para Você), do PMDB, coligou-se somente com o PHS. Todavia, para a distribuição do tempo de televisão, os partidos recebem uma cota proporcional e outra baseada na representação política. Assim, o fato de o candidato Quintão ser filiado ao PMDB significou que pôde angariar $19 \%$ do tempo de propaganda no primeiro turno, ou 5 minutos e 23 segundos. Jô Moraes (PC do B/ PRB) contava com somente 1 minuto e 46 segundos.

De acordo com Holbrook (1996), a campanha intervém sobre a opinião pública. No início, o eleitor tem uma percepção genérica dos candidatos. Com o desenrolar do jogo político, a campanha dissemina informações que são digeridas pelo eleitor e este as usa para tomar decisões. Espera-se assim que, ao provocar eventos políticos, a campanha possa alterar a avaliação inicial que o eleitor tinha dos candidatos. Naturalmente, se os candidatos dispõem de mais tempo na televisão, maior o volume de informações que poderão apresentar para o eleitor e mais sofisticados podem ser os argumentos de persuasão. ${ }^{12}$

Pelos dados do Ibope, ${ }^{13}$ o número de indecisos nas pesquisas e as intenções de votos espontâneos passaram de 70\% do eleitorado, em agosto de 2008 (an-

11 O principal evento desta "campanha negativa" foi a aparição de um vídeo no HGPE, no segundo turno, no qual Leonardo Quintão, durante uma convenção realizada em período anterior em sua cidade natal (Ipatinga/MG), afirmava que iria "chutar a bunda de seus adversários". A resposta da campanha de Lacerda (PSB/PT) foi a ampla distribuição de material de campanha - adesivos, camiseta, panfletos e mailings - com o slogan "Minha Bunda Ninguém Chuta", tema que passou a ser o foco da campanha do PSB/PT. A internet desempenhou um papel importante na disseminação de boatos e ataques aos candidatos.

12 Figueiredo e Aldé (2003) mensuraram os efeitos agregados da propaganda política sobre a intenção de voto nas eleições de $1989 / 2002$. 13 Fonte: Ibope. As pesquisas foram realizadas com 805 eleitores e os números apresentados têm uma margem de erro de 3 pontos porcentuais. 


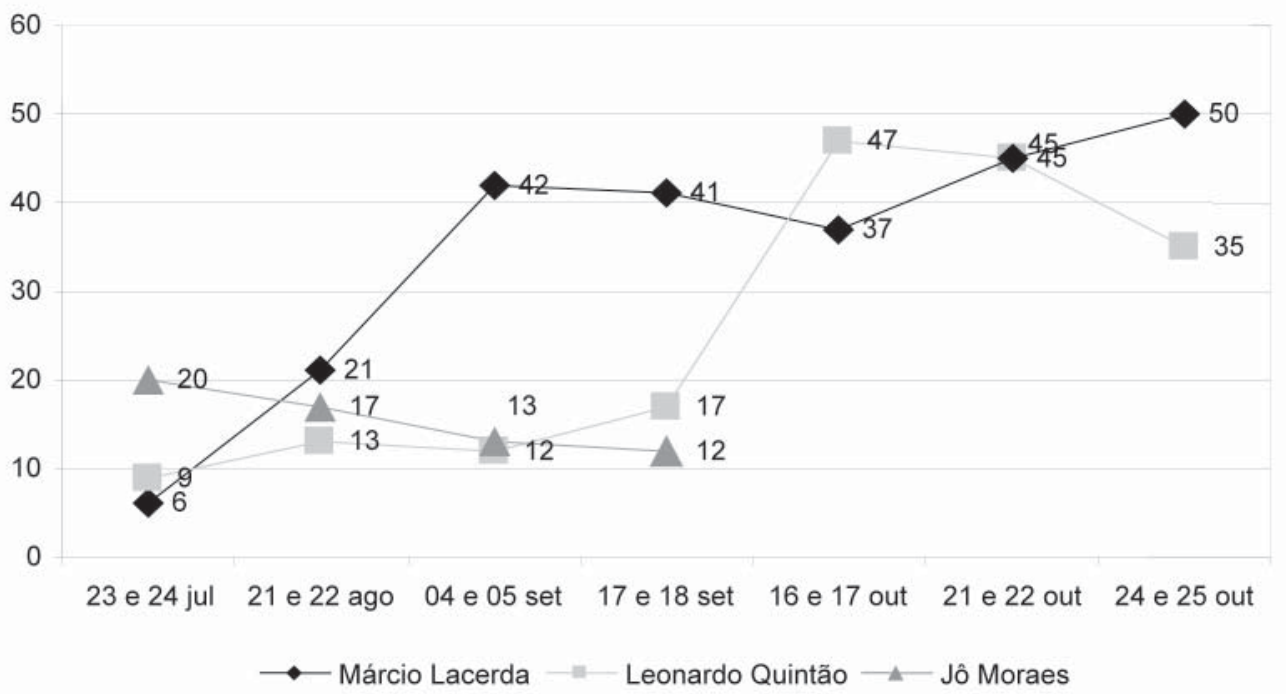

Fonte: Datafolha

tes do HGPE), para 51\% em 26 de agosto (a primeira medição depois da entrada do HGPE). Nas intenções de voto estimuladas, essa queda é de $52 \%$ para $30 \%$. Para essa caída significativa da indecisão, na ausência de outros atos que poderiam alterar inesperadamente a intenção de voto, o que mais chama a atenção é o início do HGPE na televisão e no rádio. Em função disso, podemos evidenciar a configuração de um fato de ativação atribuído ao HGPE, pela literatura (Lourenço, 2001; Aldé e Figueiredo, 2003), e das campanhas eleitorais, de um modo mais geral (Lazarsfeld e Berelson, 1960).

O tempo de programa dos candidatos também nos oferece um indício importante do significado que foi o horário eleitoral para as preferências eleitorais. Os candidatos que tiveram mais tempo de programa também foram os que ganharam mais intenções de voto. Com a entrada ao ar do HGPE, o candidato Lacerda, que tinha 11 minutos e 47 segundos de programa, salta de $9 \%$ para $40 \%$ nas intenções estimuladas, e de $5 \%$ a $31 \%$ nas espontâneas, segundo o Ibope. Durante todo o período da campanha do primeiro turno, Lacerda acumulou um saldo positivo de ganho de intenções de voto estimuladas de cerca de 30 pontos percentuais. ${ }^{14}$

Leonardo Quintão, com o segundo maior tempo, 5 minutos e 23 segundos, também cresceu em intenções de voto, acumulando um saldo positivo de 21

Tabela 1. Campanha: prestação de contas e tempo no HGPE dos candidatos a prefeito de Belo Horizonte, 2008.

\begin{tabular}{|c|c|c|c|c|c|c|}
\hline \multicolumn{4}{|c|}{ Despesas de Campanha* } & \multicolumn{3}{|c|}{ Tempo no HGPE ( $1^{\circ}$ turno) ** } \\
\hline Candidato & Partido & Total das despesas $(\mathrm{R} \$$ ) & $\%$ do total dos gastos & Coligação & Tempo total & $\%$ relativa \\
\hline Márcio Lacerda & PSB & 2121821 & 69,46 & Aliança por BH & $11 ' 47$ '61 & 41 \\
\hline Leonardo Quintão & PMDB & 485973,5 & 15,91 & $\begin{array}{c}\text { Belo Horizonte Para } \\
\text { Você }\end{array}$ & $05^{\prime} 23^{\prime \prime} 61$ & 19 \\
\hline Jô Moraes & PCdoB & 257670,8 & 8,44 & BH é Você & $01^{\prime} 46^{\prime \prime} 20$ & 6 \\
\hline Gustavo Valadares & DEM & 129905 & 4,25 & DEM & $04 ' 10 ' 20$ & 14 \\
\hline Sérgio Miranda & PDT & 55378,1 & 1,81 & BH Pode Mais & $02 ' 14^{\prime \prime} 43$ & 8 \\
\hline Jorge Periquito & PRTB & 1500 & 0,05 & $\begin{array}{c}\text { Certeza de Um Futuro } \\
\text { Melhor }\end{array}$ & $01^{\prime} 06$ '67 & 4 \\
\hline Vanessa Portugal & PSTU & 1380 & 0,05 & $\begin{array}{c}\text { Frente de Esquerda } \\
\text { Socialista }\end{array}$ & $01^{\prime} 15^{\prime \prime} 14$ & 4 \\
\hline Pedro Pinheiro & PCO & 1000 & 0,03 & PCO & $01^{\prime} 06^{\prime \prime} 67$ & 4 \\
\hline
\end{tabular}

Fontes Bases: * TSE (Prestação de Contas - $2^{\circ}$ parcial); **TRE - MG. Dados tratados e calculados pelos autores.

14 Para o cálculo desse saldo se subtraiu o percentual da última medição de intenção de voto antes do início da campanha na televisão (13 de agosto de 2008) do percentual de intenção de voto na última medição feita pelo lbope (2 de outubro de 2008). 
pontos nas pesquisas estimuladas. Os dois candidatos também apresentaram os maiores orçamentos para a campanha, representando, somente a campanha de Lacerda, $65 \%$ do total gasto por todas as campanhas de 2008. Devido a isto, temos indícios sobre dois fatores importantes para o êxito das campanhas televisivas: tempo de programa e fundos usados para a preparação de programas difundidos no HGPE..$^{15}$

As diferenças de exposição na televisão parecem ter repercutido nos movimentos dos eleitores. No início da campanha, ainda em julho de 2008 e antes do início do programa eleitoral gratuito na televisão, o número de indecisos era elevado. A candidata comunista Jô Moraes (PC do B) liderava as pesquisas de opinião, com $20 \%$ das intenções de voto. Márcio Lacerda, um técnico desconhecido, amargava 6\% das preferências. Todavia, tão logo teve início a propaganda veiculada na televisão, em agosto de 2008, a "Aliança por BH" consegue uma notável recuperação e passa para a dianteira, comandando as pesquisas até a última semana que antecedeu o primeiro turno. O número de indecisos nas primeiras rodadas das pesquisas apresentava-se bastante alto, e o início do HGPE teve o efeito de ativar o interesse pela campanha, alterando bruscamente as posições dos candidatos.

Assim, ocorreu uma brusca oscilação do eleitorado nos momentos finais do primeiro turno, o que pode ter sido gerado pelo principal evento da campanha nesse período: o debate. $\mathrm{O}$ debate entre os principais candidatos, promovido pela TV Globo no dia 2 de outubro, dois dias antes do primeiro turno, pode ter sido uma fonte importante de informação para o eleitor reforçar ou converter o seu voto. Entre os que assistiram ao evento, 38\% afirmaram que Quintão se saiu melhor e 29\% afirmaram que Márcio Lacerda foi melhor no debate (Datafolha).

Ainda que nenhuma das pesquisas houvesse logrado captar essa alteração, os eleitores contrariaram frontalmente as análises, que mostravam Lacerda com folgada liderança. Diante das urnas, Leonardo Quintão (PMDB), que aparecia nas pesquisas com $17 \%$ das preferências em 17 de setembro, obteve 41,26\% dos votos, em situação de empate técnico com Lacerda (43,59\%). A terceira colocada, a candidata Jô Moraes, do $\mathrm{PC}$ do $\mathrm{B}$, obteve $9 \%$. Os demais partidos que apresentaram candidatos - DEM, PDT, PRTB, PT do B, PCO e PSTU - somaram juntos 6\%.

No início do horário eleitoral, no segundo turno, com iguais 10 minutos de propaganda para cada candidato, Quintão continuou com curva ascendente, chegando a ter mais de 10 pontos percentuais a frente do PSB/PT. Mas, às vésperas das eleições, as pesquisas realizadas entre os dias 24 e 25 de outubro (Datafolha) ainda apresentam $16 \%$ de eleitores sem candidatos. A enorme vantagem de Quintão se esvaeceu e o peemedebista chegou em segundo lugar, com 40,88\% dos votos válidos. Essa volatilidade do eleitor, que se comportou oscilando ao longo da campanha, reforça a determinação das variáveis conjunturais nessas eleições municipais. ${ }^{16}$

A enorme variação nas intenções de voto e o percentual de indecisos determinaram um lugar especial para as campanhas na capital. Os eleitores foram expostos a uma quantidade de ataques e críticas pessoais entre os candidatos sem precedentes na história política local. Diante de um contexto de polarização nacional entre o PT e o PSDB, vale a pena indagar como o eleitor reagiu diante de um cenário municipal no qual tal confronto não foi reproduzido. Sem a reprodução dessa polarização, as identidades partidárias funcionaram como um atalho para o voto? A seção a seguir apresenta algumas hipóteses explicativas sobre a decisão do voto em Belo Horizonte. Vamos realizar o diálogo com algumas teorias retiradas dos paradigmas macro e microestruturais, para explicar algumas facetas do comportamento do eleitor na capital mineira.

\section{III - A decisão de voto: modelos teóricos e seus indicadores}

O que se busca neste artigo é compreender as lógicas do voto nas eleições municipais de 2008. Para tanto, devemos trabalhar com a intenção de voto tanto no primeiro quanto no segundo turno. Porém, comparações realizadas entre os dois turnos utilizando apenas cruzamentos simples são insuficientes para apreender a complexidade dessas eleições de Belo Horizonte. Por isso, consideramos que o mais adequado é o tratamento dos dados com o uso de estatísticas multivariadas, a fim de corroborar ou refutar, através de medidas significativas, se ocorreram motivações diferenciadas para o voto, em cada um dos candidatos e em cada um desses dois turnos.

A decisão de voto é um fenômeno complexo e responde a causas múltiplas. Por isso, a necessidade de construir um modelo que dê conta dessa pluralidade. Usualmente, para o estudo da decisão de voto, são tra-

15 Apenas teríamos uma prova mais robusta desses indícios, como fatores gerais para o êxito da campanha televisiva, se fizessem um teste de correlação abarcando outras variáveis, o que agora não é o nosso propósito.

16 Deve-se ressaltar que, de acordo com a pesquisa Ipespe/UFMG, no primeiro turno, 17\% dos eleitores afirmaram que já haviam decidido o seu voto antes da campanha e outros 11,5\% no inicio da campanha. Assim, havia espaços para mudanças e, ao que parece, a campanha favoreceu inicialmente sobretudo a Leonardo Quintão, cujos eleitores foram mais suscetíveis a este evento: no segundo turno, 40\% dos seus eleitores afirmaram que decidiram o seu voto durante a campanha. 
tadas variáveis clássicas de identidade partidária, imagem dos candidatos, avaliações políticas e econômicas prospectivas e retrospectivas, variáveis sociodemográficas e geográficas. O ideal é que, além dessas, sejam inseridas variáveis que reflitam as especificidades do quadro eleitoral que se pretende analisar.

O modelo estatístico utilizado será o de regressão logística multinomial e foi inspirado no modelo que Alejandro Moreno (2003) utilizou para avaliar as atitudes políticas e a conduta eleitoral dos votantes no México. A explicação para a intenção de voto em candidatos a prefeito incorporará alguns aspectos retirados das principais teorias sobre o comportamento do eleitor. Exploraremos a capacidade preditiva da satisfação com os governantes e com economia; a identidade partidária, a autolocalização nas escalas de esquerda-direita, a avaliação e a exposição à campanha eleitoral sobre a intenção de voto.

Os dados a serem analisados repousam em duas pesquisas do tipo survey, com entrevistas vis-à-vis, que foram realizadas no primeiro e segundo turnos das eleições municipais de 2008. O primeiro survey abarcou 800 eleitores com mais de 16 anos e foi realizado entre os dias 23 e 27 de setembro de 2008; outro foi realizado com 800 eleitores, maiores de 16 anos, no segundo turno, entre 19 e 22 de outubro de 2008. O tamanho do erro amostral de cada survey foi de 3,1 pontos percentuais (pp)

A seguir, os indicadores e a distribuição das frequências das variáveis selecionadas para análise. ${ }^{17}$

\section{III.1. Medidas e indicadores}

\section{Identidades coletivas}

$\mathrm{Na}$ corrente sociológica os comportamentos e atitudes políticas têm conexão com a inserção dos indivíduos em processos coletivos, que produzem identidades sociais, resultantes de interesses. Tais identidades comandam as decisões de voto. $\mathrm{O}$ modelo explora as articulações entre o voto e o gênero, a idade (mais jovens e mais velhos), a renda (em sa- lários mínimos) e a escolaridade (menor ou maior) do eleitor, nos dois turnos. Não podemos construir expectativas de como associar o voto nos candidatos com essas variáveis, tendo em vista que não há estudos pormenorizados acerca do comportamento do eleitor de Belo Horizonte. ${ }^{18}$

\section{Voto retrospectivo e voto econômico}

Conforme discutido, a decisão do votante pode estar associada ao voto retrospectivo e econômico. A teoria aqui subjacente é a de que o eleitor vota como um juiz, avaliando os resultados políticos e econômicos, punindo o governo, quando as coisas estão mal, e apoiando-o, quando as coisas estão bem. Essa teoria tem a expectativa que o voto reflita o desempenho do partido ou candidato em seu passado; portanto, a noção é a de que votar é um ato de penitenciar ou de recompensar os partidos. O esperado pela teoria é que avaliações positivas do desempenho político-econômico atuem no sentido de aumentar as possibilidades de voto na situação, ao passo que percepções negativas beneficiem a oposição ao governo. Na realidade, o voto retrospectivo e o prospectivo são combinados, pois as avaliações do passado são utilizadas para fazer projeções sobre o futuro.

Os indicadores usuais da literatura e que serão utilizados no modelo nos dois turnos das eleições são a avaliação que o eleitor faz dos governos, nos planos municipal, estadual e federal; a satisfação do votante com a sua vida pessoal; o julgamento do eleitor acerca do desempenho da economia nacional. ${ }^{19} \mathrm{O}$ problema do voto retrospectivo em Belo Horizonte é o de que, no discurso da campanha, tanto Quintão quanto Lacerda se apresentaram como "continuadores" do projeto do prefeito. De qualquer forma, ainda com essa ressalva, o esperado é que a avaliação positiva da administração municipal premie o candidato Lacerda nas urnas, pois este era apoiado pelo prefeito, e a avaliação negativa da conjuntura político-econômica represente votos para Jô Moraes, candidata da "oposição". ${ }^{20}$

17 Os dados deste artigo representam somente parcialmente o survey Ipespe/UFMG, cujo questionário apresentou blocos referentes aos temas da representação política, participação não eleitoral, imagem dos candidatos, confiança nas instituições, valores e atitudes dos eleitores. As questões e escalas construídas foram confrontadas com outros surveys produzidos pelo Centro de Investigación Sociológica (CIS/Espanha). As pesquisas foram registradas, no primeiro turno, no TRE/MG, sob o número 72335/2008 e, no segundo turno, sob o registro 80845/2008.

18 De acordo com Kinzo (2005), a probabilidade de um eleitor de nível médio de escolaridade manifestar preferência pelo PT é 1,3 vezes maior do que um eleitor de nível baixo, probabilidade esta que passa a 1,6 vezes no caso daqueles de nível alto de escolaridade. Não podemos assumir os resultados da pesquisa Região Metropolitana de São Paulo no sentido de ter uma expectativa de que a escolaridade explique o voto em Lacerda, candidato apoiado pelo PT, pois nossa variável dependente não é a identidade com o partido.

19 As perguntas foram fechadas e elaboradas das seguintes formas: (i) Gostaria que o senhor avaliasse a administração do (governante); (ii) De maneira geral, o senhor diria que está satisfeito com sua vida?; (iii) O senhor diria que a situação econômica atual do país está..

200 problema se remete a outras dimensões. A própria confusão do sistema partidário brasileiro, que permite coligações, dificulta expectativas de voto retrospectivo. Primeiro, porque nas atuais condições em que o presidente Lula da Silva atingiu mais de 70\% de aprovação, a maior parte dos partidos tenta se associar ao presidente; em segundo lugar, a candidata Jô Moraes se apresentava como oposição ao candidato apoiado pelo prefeito Fernando Pimentel (PT), mas seu partido participou da administração deste prefeito. E, no plano federal, o PC do B faz parte da base aliada do governo federal. 


\section{Autolocalização esquerda-direita}

Um fator relevante para a escolha racional, e levada em conta na análise, é a distribuição do eleitorado na escala político-ideológica, ou seja, numa escala entre esquerda e direita. Seguindo a teoria downsiana, a repartição dos eleitores nessas escalas seria determinante para a emergência e estratégias dos partidos. Harold Hotelling (1929) propôs um modelo econômico no qual duas firmas (ou partidos políticos) poderiam dividir um espaço entre si ao longo de uma escala ideológica. Do modelo, resulta que, quando os eleitores se distribuem uniformemente nessa escala, o partido que atua de modo a maximizar o voto move sua plataforma no sentido de se aproximar do adversário para poder captar os votantes mais próximos ideologicamente do partido oponente.

Esse mecanismo teria duas consequências diretas: os partidos teriam um incentivo à aproximação ideológica; e o comportamento maximizador de votos levaria a resultados socialmente indesejáveis, já que a distância geral ideológica tomada no conjunto de todos os eleitores aumentaria quando da ocorrência do movimento para o centro. Anthony Downs (1957) desenvolveu essa ideia, dando maior atenção às possibilidades de distribuição dos eleitores na escala ideológica. Resulta que a distribuição é essencial para a localização do eleitor médio e, logo, para a estratégia das plataformas partidárias, permitindo uma estratégia de aproximação ou de distanciamento ideológico.

Mais tarde, novas contribuições foram adicionadas ao modelo. Albert Hirshman (1970) critica a inelasticidade da demanda dos eleitores na escala ideológica do modelo anterior. O autor desenvolveu um mecanismo de ativismo e mobilidade social (voice) e que também influenciaria a estratégia partidária. No Brasil, André Singer (2000) procurou demonstrar a importância do tema ao fazer um estudo da teoria e análises do aspecto da posição ideológica do eleitor e argumentou que esse posicionamento baliza o eleitor na hora da decisão do voto para presidente e tem se mostrado estável ao longo do tempo.

Neste artigo, assumimos as conclusões de Almeida (2001) e consideramos que a escala de autolocalização esquerda-direita, no Brasil, não se constitui como indicador de ideologia. Os diversos estudos realizados e em desenvolvimento demonstram que não há consen- so, e a literatura ainda não apresentou indicadores consistentes capazes de mensurar a ideologia ${ }^{21}$ Trataremos essa escala como indicador de distribuição espacial e realizaremos os testes. Caso a escala seja um indicador de ideologia, a expectativa seria a de que a autolocalização do eleitor à esquerda explicasse o voto em Lacerda, candidato apoiado pelo PT, ou em Jô Moraes, do PC do B. A questão para essa pergunta foi a de apresentar ao eleitor uma escala numerada, de 0 a 10, e o informante deveria escolher em qual posição ele se colocaria nesse contínuo, em que "0" e "10" representam extrema esquerda e extrema direita, respectivamente.

\section{Preferência por partido}

Uma parte da literatura assegura que a identidade com os partidos tem uma forte associação com o voto. ${ }^{22}$ A preferência por partidos é considerada como um importante fator para explicar a atitude e a conduta dos votantes e se converteu em um importante preditor tanto para a participação quanto para o interesse pela política, a aprovação dos candidatos, a avaliação do desempenho dos governantes e mesmo para a resistência às propostas políticas. Nesse sentido, os identificados com partidos teriam mais interesse em acompanhar as campanhas, pois seriam cidadãos mais ativos. Ademais, de algum modo, a preferência por partido "filtraria" e modularia as opiniões que os votantes têm dos líderes e partidos.

Explicar as razões pelas quais os eleitores se identificam com partidos políticos passou a ser uma questão importante para os pesquisadores que se debruçam sobre o tema do comportamento eleitoral. Contudo, a identificação não apresenta necessariamente uma relação com as propostas que são defendidas pelos partidos ou seus candidatos, durante os processos de campanha eleitoral. A medição de identidade partidária se leva através tanto da direção quanto da intensidade dessa identificação. Não se tratará aqui de examinar o conteúdo e razões dessa identificação, mas importa assinalar que o conceito foi remodelado em diversas ocasiões e outras revisões acabaram por simplesmente reduzir o conceito de identidade partidária a uma determinada predisposição do eleitor que funcionava como redutor de custo de informação (Popkin, 1991). No modelo, vamos tratar a identidade partidária nesse sentido "fraco" do termo. Assim, a pergunta estimu-

21 Em artigo recente, Samuels (2008, p. 311) chegou a afirmar que "a comparação entre 2002 e 2007 revela mudanças intrigantes nas bases do petismo. A distinção mais óbvia é que a ideologia esquerda-direita não prediz mais o petismo. Em 2002, os petistas ainda se autolocalizavam levemente à esquerda em comparação aos brasileiros sem identificação partidária, a categoria base". Mas tal afirmativa apenas faria sentido no caso de os eleitores conhecerem corretamente os conceitos de direita/esquerda, de acordo com o mesmo significado atribuído pela Ciência Política. A esse respeito, Carreirão (2002; 2007) apresenta resultados do controle desta escala controlada pela escolaridade; Telles (2008a) realizou grupos focais com o eleitorado de Belo Horizonte com o intuito de explorar os conteúdos atribuídos a esta escala. Os resultados parciais apenas confirmam ausência do conhecimento destas categorias por parte do eleitor, que define a direita como "situação e ação correta" e a esquerda como "oposição e fazer coisas erradas".

22 Além de Reis (1978), em relação ao tema da identidade com partidos no Brasil, estudos mais recentes são os de Kinzo e Braga (2007) e Veiga (2007). 
lada nos dois turnos foi "qual é o partido político de sua preferência, aquele que o (a) Sr.(a) mais gosta ou que mais representa a sua maneira de pensar".

\section{A exposição à campanha: o Horário Gra- tuito de Propaganda Eleitoral}

As estratégias das campanhas eleitorais televisivas constituem um fator que influencia os resultados de uma eleição? Como vimos, os apontamentos e os achados heurísticos recentes da literatura sobre mídia e política nos apontam para uma resposta positiva a essa questão. Sabe-se que a imagem se tornou um importante componente das campanhas, sobretudo em sociedades como a nossa em que nas últimas décadas a disputa político-eleitoral foi alçada ao mundo televisivo (Rubim, 2000; Almeida, 2001; Albuquerque, 1996; Silveira, 1998). Hoje, no Brasil, fica difícil imaginar uma fonte de informação política mais eficaz que a mídia e uma forma de conhecer os programas de governo dos diferentes partidos melhor que os programas do Horário Gratuito de Propaganda Eleitoral (HGPE).

Essa variável nos parece relevante para ser controlada, não apenas por razões de ordem teórica, como já dito, mas por sua possível capacidade para afetar a decisão do voto, em Belo Horizonte. O início da campanha eleitoral, e mais especificamente do Horário Gratuito de Propaganda Eleitoral (HGPE), foi um momento importante na ativação da preferência eleitoral do belorizontino. Isso fica mais claro quando observamos como se comportaram os eleitores espontaneamente indecisos numa linha temporal nas pesquisas de opinião dos institutos de pelos menos dois momentos: antes e depois da veiculação do HGPE.
O HGPE foi selecionado como o principal elemento da campanha, tendo em vista outros estudos já apresentados. Como indicador de exposição à campanha, utilizamos a frequência com que o eleitor acompanhou os programas gratuitos de propaganda eleitoral; outro indicador foi a avaliação que o eleitor fez desse programa. Sabe-se que as informações produzidas pelas campanhas podem ser mediadas pelas fontes de identidades que o indivíduo tem previamente. O eleitor pode assistir à campanha e selecionar informações que reforcem seus argumentos prévios; ou as informações divulgadas pela campanha podem ter o efeito de converter preferências. ${ }^{23}$ Uma ressalva importante a ser feita é a de que este artigo trata somente de examinar se a exposição à campanha se encontra associada ao voto, sem adentrar no mérito do mecanismo de reforço ou conversão do voto.

Partindo da hipótese de que a exposição à campanha tem efeitos sobre o voto, espera-se que o eleitor que acompanhe o HGPE vote em Márcio Lacerda, pois este é o candidato com mais tempo de propaganda, tanto no rádio quanto na televisão, no primeiro turno. No segundo turno, os efeitos da exposição devem ser reduzidos, devido ao tempo dos programas ser semelhante. Portanto, a direção do voto passaria a depender mais de outros fatores, como a avaliação de cada programa eleitoral.

Por outro lado, outra teoria seria a de que, ao ser exposto ao HGPE, o eleitor avalia as imagens e os discursos que lhe são ofertados. Assim, a expectativa é a de que a avaliação positiva de um programa explique a intenção de voto no candidato. ${ }^{24} \mathrm{~A}$ exposição é indicada pela frequência com que o eleitor acompanhou o HGPE - nunca, raramente, de vez em quando e

Tabela 2. Análise de satisfação individual e avaliação econômica do país (\%)

Grau de satisfação com a própria vida

\begin{tabular}{llll}
\hline Nada satisfeito & $3 \%$ & péssima & $7 \%$ \\
Pouco satisfeito & $10 \%$ & ruim & $13 \%$ \\
Mais ou menos satisfeito & $36 \%$ & regular & $48 \%$ \\
Muito satisfeito & $51 \%$ & boa & $29 \%$ \\
& & ótima & $3 \%$
\end{tabular}

$\mathrm{N}=797$

$100 \%$

$\mathrm{N}=798$

$100 \%$

Fonte: Pesquisa "A decisão de voto em eleições municipais", realizada pelo DCP/ UFMG e Instituto de Pesquisas Sociais, Políticas e Econômicas (Ipespe), primeiro turno.

23 Qualquer desses efeitos apenas poderia ser mensurado controlando-se as preferências do eleitor em tempos distintos: antes e depois da exposição ao HGPE, o que exigiria técnica de painel.

24 Novamente deve ser ressaltado que este artigo não avalia os fatores psicológicos que podem estar presentes na produção da avaliação dos méritos das campanhas. A avaliação dos programas através de notas dadas pelos eleitores foi utilizada por Lourenço (2007) para analisar a relação entre as avaliações dos programas do HGPE e as avaliações de simpatia, plano de governo, experiência política, confiança e preparo dos candidatos. O método também serviu para compor um modelo de regressão logística binária que relacionou a avaliação dos programas do HGPE e as possibilidades de voto em Lula em 2002. 
Tabela 3. Avaliação das administrações do presidente, governador e prefeito (\%)

\begin{tabular}{lccc}
\hline & Presidente Lula & Governador Aécio Neves & Prefeito Fernando Pimentel \\
\hline péssimo & $5 \%$ & $4 \%$ & $2 \%$ \\
ruim & $4 \%$ & $1 \%$ & $2 \%$ \\
regular & $23 \%$ & $12 \%$ & $18 \%$ \\
bom & $49 \%$ & $46 \%$ & $48 \%$ \\
Ótimo & $19 \%$ & $36 \%$ & $29 \%$ \\
\hline Total & $100 \%$ & $100 \%$ & $100 \%$ \\
$\mathrm{n}$ & $(798)$ & $(798)$ & $(796)$ \\
\hline
\end{tabular}

Fonte: Pesquisa "A decisão de voto em eleições municipais", realizada pelo DCP/ UFMG e Instituto de Pesquisas Sociais, Políticas e Econômicas (Ipespe).

sempre - e a avaliação é a nota estimulada em todos os programas, de 0 a 10 , no qual " 0 " é péssimo e "10" é ótimo.

\section{III.2. Distribuição das frequências}

A seguir, apresentamos ao leitor as distribuições das respostas a esse conjunto de variáveis. Iniciamos esta exposição pela análise de satisfação individual e avaliação da economia e das administrações.

Quanto à satisfação com a própria vida, nota-se que apenas 3\% dos eleitores estavam nada satisfeitos e $20 \%$ acreditavam que a situação econômica do país estava entre ruim e péssima.

$\mathrm{Na}$ avaliação das administrações, a Tabela 3 indica que os três governantes - o prefeito Fernando Pimentel (PT), o governador Aécio Neves (PSDB) e o presi- dente Lula da Silva (PT) - foram muito bem avaliados pelos entrevistados, situando-se majoritariamente na escala bom e ótimo. Esses números apontam para um quadro favorável para o candidato que representasse retoricamente a manutenção do status quo político, uma vez que os índices de satisfação com o mundo presente eram bastantes altos em Belo Horizonte. O significado político que pode ser retirado dessa avaliação é a de que dificilmente a retórica oposicionista poderia ser apresentada pelos candidatos, sob pena de serem rechaçados nas urnas.

Como se pode observar pelo Gráfico 2, mais da metade das observações (56\% dos eleitores) se localizou ao centro; $26 \%$ se agruparam à direita e $16 \%$ na categoria correspondente à esquerda. ${ }^{25}$ De acordo com tais dados, o espaço político em Belo Horizonte estaria concentrado ao centro, o que explicaria a

Gráfico 2. Autolocalização na escala política esquerda-direita (\%)

口escala esquerch-direita (D a 10)

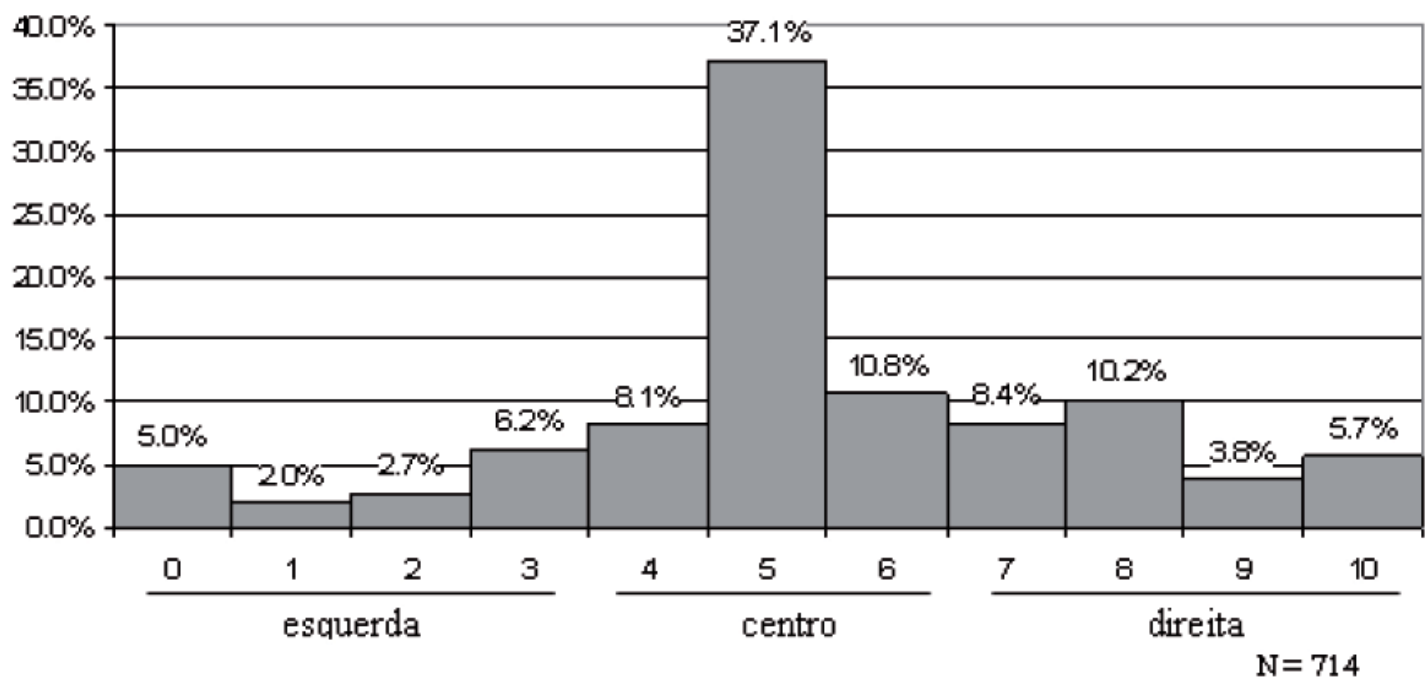

Fonte: Pesquisa "A decisão de voto em eleições municipais", realizada pelo DCP/ UFMG e Instituto de Pesquisas Sociais, Políticas e Econômicas (Ipespe).Obs.: 1)As posições na escala de 0 a 10 foram assim agrupadas: esquerda: 0 a 3; centro: 4 a 6; direita: 7 a 10. 2) Não foram aqui considerados os eleitores que não se posicionaram na escala ou não sabiam ou não responderam à pergunta sobre o posicionamento ideológico (11\% da amostra).

25 Valores semelhantes foram encontrados para o Brasil no Informe Latinobarómetro de 2008. Seguindo a mesma metodologia, obteve-se $48 \%$ ao centro, $14 \%$ à esquerda e $22 \%$ à direita, valores também próximos à média latina. 
Gráfico 3. Preferência partidária em Belo Horizonte, $1^{\circ}$ e $2^{\circ}$ turnos de 2008

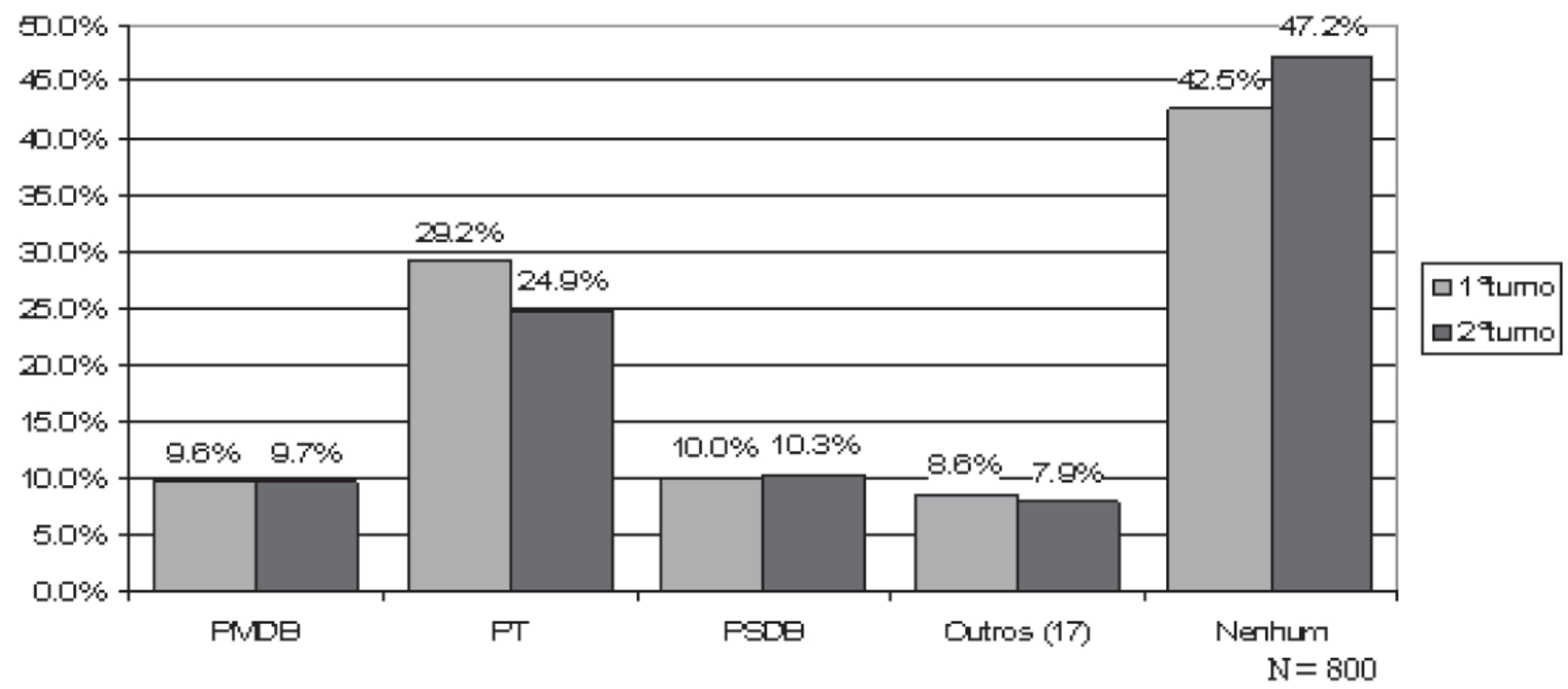

Fonte: Pesquisa "A decisão de voto em eleições municipais", realizada pelo DCP/ UFMG e Instituto de Pesquisas Sociais, Políticas e Econômicas (Ipespe).

decisão dos partidos PT e PSDB em se coligarem, eliminando as barreiras para os eleitores identificados com esse ponto, já que a representação desses eleitores poderia levá-los à vitória.

No Gráfico 3, apresentamos a preferência partidária, variável de impacto eleitoral direto e que se relaciona com todos os níveis de governo numa democracia. No caso de Belo Horizonte, essa variável tornou-se complexa por não ter havido uma indicação direta de candidatos do partido do prefeito (PT) e do governador (PSDB), que são os partidos mais relevantes, como indica o Gráfico 3.

$\mathrm{Na}$ descrição, nota-se o elevado número de eleitores com preferência por partidos, bem acima da média nacional. A maior preferência recai sobre o PT, apesar de ser menor o número de entrevistados que se autodeclararam como de esquerda.

Uma análise de grande interesse neste trabalho é a influência do HGPE na decisão do voto. As categorias de frequência de exposição ao voto no $1^{\circ}$ e $2^{\circ}$ turnos mostram índices importantes.

Quanto à audiência, apenas 1/4 dos eleitores afirmaram que nunca assistiam ao HGPE no primeiro turno; esse número cai mais no segundo turno, indicando um aumento do envolvimento dos eleitores nesse período da campanha. Nota-se que a exposição ao HGPE aumenta com a aproximação do segundo turno. Apesar do tom negativo das campanhas, a
Tabela 4. Exposição ao Horário Gratuito de Propaganda Eleitoral (HGPE)

\begin{tabular}{ccc}
\hline & $1^{\circ}$ turno & $2^{\circ}$ turno \\
\hline todo dia & 90 & 121 \\
& $(11 \%)$ & $(15 \%)$ \\
às vezes & 249 & 304 \\
& $(31 \%)$ & $(38 \%)$ \\
raramente & 263 & 198 \\
& $(33 \%)$ & $(25 \%)$ \\
nunca & 191 & 177 \\
& $(24 \%)$ & $(22 \%)$ \\
\hline total & 793 & 800
\end{tabular}

Fonte: Pesquisa "A decisão de voto em eleições municipais", realizada pelo DCP/UFMG e Instituto de Pesquisas Sociais, Políticas e Econômicas (Ipespe)

maioria dos eleitores se expôs, em alguma medida, a essa propaganda. Como já dito, tendo em vista uma campanha baseada na ausência tanto de diferenciação entre partidos, importante atalho cognitivo, como de um esquema clássico de oposição/situação, o eleitor deveria buscar em outras fontes - mídia, amigos, lideranças - elementos para subsidiar sua decisão, o que conferiu ainda mais relevância ao HGPE, como fonte de informação. ${ }^{26}$

Finalmente, a última variável a ser utilizada no modelo é a avaliação da campanha dos candidatos.

26 Uma das hipóteses que poderão ser exploradas futuramente é a de que o voto em Belo Horizonte tendeu a ser baseado nas imagens construídas pelos candidatos. Silveira (1998) afirma que o "novo eleitor não racional" escolhe os seus candidatos a partir de um modelo de "bom político", que seria o ideal de político. Qualidades como honestidade e competência seriam os principais atributos buscados pelos eleitores. Todavia, discordamos que o caráter desta escolha possa vir a caracterizar o eleitor como "não racional", discussão que não será examinada neste artigo. Os resultados das imagens das campanhas e o voto foram apresentados por Telles (2008b) no $1^{\circ}$ Simpósio Nacional de Marketing Político e Opinião Pública, realizado no DCP/UFMG, em novembro de 2008. 
$\square$ baixa $(0-4) \square$ média $(5-7) \square$ alta $(8-10)$

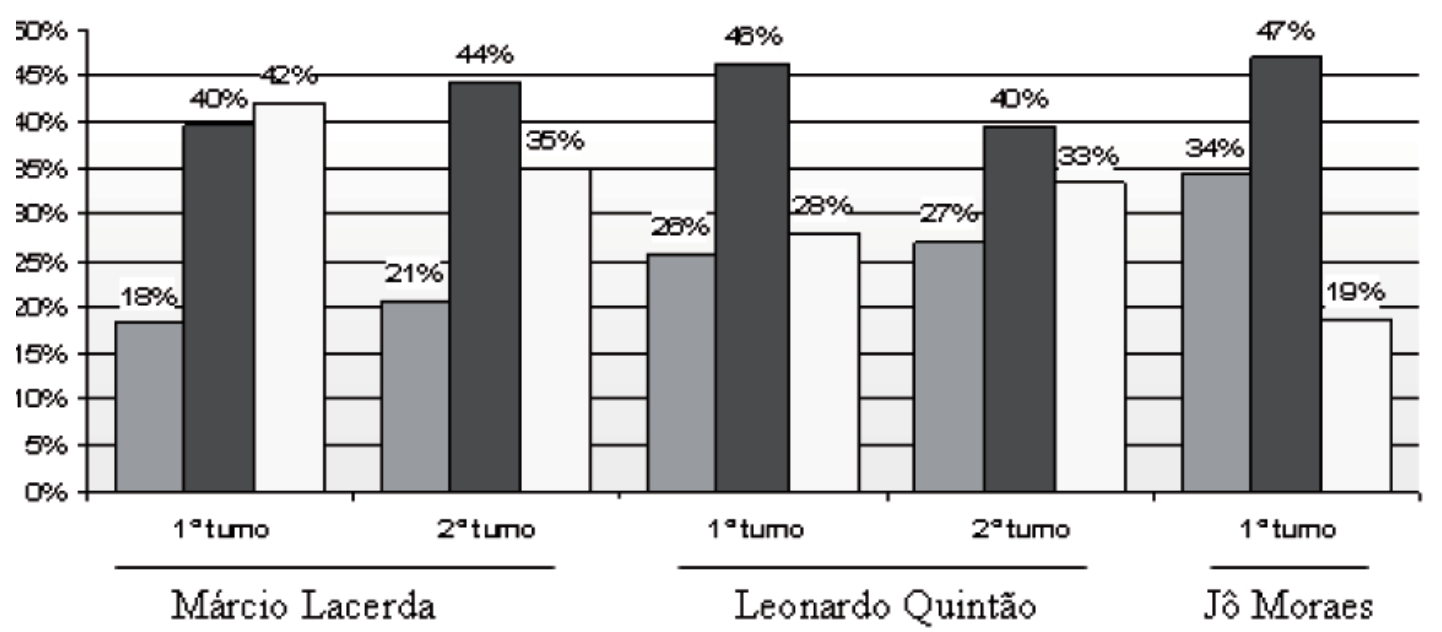

Observa-se que a nota média da avaliação do programa de HGPE de Lacerda era de 6,4, valor que praticamente permaneceu no segundo turno $(6,1)$; já as notas ao programa eleitoral do peemedebista ficaram em torno de 5,8 no primeiro turno e 5,7 no segundo. A comunista Jô Moraes teve uma avaliação menos positiva de seu programa televisivo, que obteve nota média de 5,1. Contudo, a média vista isoladamente aqui não é uma boa medida para expressar a magnitude e a importância que a avaliação do HGPE pode ter sobre a intenção de voto, como veremos mais adiante.

\section{Metodologia: Modelo de Regressão Logística Multinomial}

Modelos estatísticos explicativos têm sido crescentemente apresentados na literatura em Ciência Política como ferramenta complementar para pensar nas várias hipóteses apresentadas pela teoria, em especial, no tema do comportamento eleitoral. O uso de um modelo econométrico pode contribuir para esclarecer os determinantes da escolha para prefeito em Belo Horizonte, em 2008, dadas as particularidades dessas eleições que, como dito, foram complexas.

Neste estudo, a variável dependente - intenção de voto em Belo Horizonte - é categórica (ou qualitativa), não ordenada (ou nominal) e, ainda, dividida em mais de duas categorias (ou multinomial). Para tratá-la aqui, utilizamos a abordagem do Modelo de Regressão Logística Multinomial, que tem a vantagem de verificar os efeitos de fatores explicativos sobre o risco relativo dos resultados, permitindo assim a análise das chances estimadas da ocorrência de um evento de interesse em relação à sua não ocorrência.
No modelo multinomial logístico, estima-se os efeitos das covariáveis para cada uma das equações em relação a uma categoria base. Aspecto interessante na determinação do nosso modelo foi levar em conta o contexto eleitoral em Belo Horizonte, captado pela amostra: a alta frequência dos entrevistados que não tinham ainda escolhido seu candidato $\left(24 \%\right.$ na $1^{a}$ rodada e $18 \%$ na $2^{a}$ rodada), o que permitiu tomar essa categoria como base de comparação. Assim, analisamos as intenções de voto em Márcio Lacerda (PSB), Jô Moraes (PC do B) e Leonardo Quintão (PMDB) em relação à base de comparação "nenhum", cujos indicadores são "não sabe/branco/nulo/nenhum". A intenção de voto em outros candidatos não é modelada e representa somente $5 \%$ da amostra. A chance é definida pela probabilidade de ocorrência do evento sobre a probabilidade de sua não ocorrência. Em nosso caso, a probabilidade de o eleitor ter a intenção de votar em um determinado candidato sobre a probabilidade de não ter candidato.

Os parâmetros que devemos estimar são calculados usando-se o estimador de máxima verossimilhança. A interpretação dos parâmetros pode ser muito profícua quando a questão de interesse é descrever as chances de sucesso ou as chances de insucesso de um grupo em relação a outro. Para a análise dessas variáveis binárias ou dummy, utilizamos o odds ratio. Para variáveis contínuas, podemos ficar com os efeitos marginais sobre as probabilidades de sucesso. O efeito marginal expressa a taxa de mudança em uma quantidade em relação à outra, uma mudança na variável dependente por unidade de mudança na variável independente.

Seguindo a linha de outros estudos eleitorais, a base da análise procura identificar efeitos de possíveis influências na decisão do voto: a exposição ao HGPE; a autolocalização do eleitor na escala esquerda-direita; a preferência partidária; a avaliação dos governantes dos outras esferas de poder; a satisfação com a vida e a sa- 
tisfação com a economia nacional. Controlam-se ainda fatores como gênero, idade, renda e estudo. Todas essas são as covariáveis modeladas e analisadas no modelo a ser apresentado. Para uma interpretação mais direta e devido ao formato da pesquisa, as covariáveis no modelo foram categorizadas de forma binária, permitindo que os odds ratio representassem riscos relativos.

Por privilegiarmos a análise com variáveis discretas e do tipo dummy, uma preocupação recorrente é a análise da ocorrência de multicolinearidade..$^{27} \mathrm{Em}$ uma forma moderada, a colinearidade ocorre quando temos alto índice de correlação entre variáveis, o que acarreta inflação dos erros-padrões dos coeficientes, daí a não eficiência e perda de confiança na estatística de Wald. Para detectar a possível presença de colinearidade, primeiramente analisamos a correlação entre as variáveis independentes. Nenhuma correlação acima de 0,5 (em módulo) foi detectada, o que indica a ausência de multicolinearidade. Realizamos ainda a estatística do Fator de Inflação da Variância (VIF), que indica o quanto a inflação dos desvios padrões podem ser causados por colinearidade, captando a interrelação entre as variáveis por meio dos ajustes das regressões entre as variáveis. A média dos VIFs (1/ (1-R2)) das variáveis independentes do modelo foi 1,17 ( $1^{\circ}$ turno) e 1,17 ( $2^{\circ}$ turno), não implicando problemas de colinearidade, como já indi- cava a baixa correlação entre as variáveis. Uma análise complementar ainda pode ser feita através do Condition Index, que leva em conta a relação entre o maior e o menor autovalores da matriz que contém as variáveis independentes. Os valores nos nossos modelos, de 11,89 ( $1^{\circ}$ turno) e 9,60 ( $2^{\circ}$ turno), podem ser considerados aceitáveis, considerando ainda o grande número de variáveis (Belsley, Kuh e Welsch, 1980).

Para testarmos ainda se podemos tratar os dados neste método de análise, no qual utilizamos uma categoria base para comparar as hipóteses explicativas, temos de verificar o pressuposto de que a escolha de um indivíduo não é afetada desde que não haja informações alternativas relevantes. A hipótese de independência das alternativas irrelevantes ou IIA $^{28}$ pode ser testada através do chamado teste de Hausman-McFadden para subconjuntos de alternativas (Hausman e McFadden, 1984). Nesse teste, estima-se o modelo logit duas vezes: no conjunto completo de alternativas e num conjunto específico. A comparação entre as diferenças nos coeficientes é analisada e testada, assegurando IIA quando os coeficientes não forem estatisticamente diferentes. Esse teste, de análise pósestimação, assim como o modelo, foi realizado usando o pacote estatístico Stata10 e aceitou a hipótese nula de IIA para as três alternativas nos dois turnos.

\section{V - Análise dos resultados ${ }^{29}$}

Tabela 5. Parâmetros do Modelo de Regressão Logística Multinomial de Intenção de Voto estimulada - $\left(1^{\circ}\right.$ turno).

\begin{tabular}{|c|c|c|c|c|c|c|}
\hline Variáveis & Categorias Dummy & Coef.(ß) & Erro Padrão & Wald (z) & Prob. $>|z|$ & Odds Ratio \\
\hline \multicolumn{7}{|l|}{ Márcio Lacerda (PSB) } \\
\hline Gênero & Masculino & -0.32 & 0.22 & -1.46 & 0.15 & 0.72 \\
\hline Idade & Jovem (16 a 24 anos) & 0.10 & 0.27 & 0.35 & 0.73 & 1.10 \\
\hline Renda Familiar & Mais de $5 \mathrm{SM}$ & 0.83 & 0.26 & 3.16 & 0.00 & 2.28 \\
\hline Escolaridade & Ensino médio e superior & -0.08 & 0.24 & -0.34 & 0.73 & 0.92 \\
\hline Preferência partidária & PMDB & 0.96 & 0.50 & 1.90 & 0.06 & 2.60 \\
\hline Preferência partidária & PT & 0.15 & 0.26 & 0.59 & 0.55 & 1.17 \\
\hline Preferência partidária & PSDB & 0.07 & 0.08 & 0.86 & 0.39 & 1.07 \\
\hline Exposição ao HGPE & Às vezes/todo dia & 0.26 & 0.25 & 1.04 & 0.30 & 1.30 \\
\hline Avaliação HGPE Lacerda (0 a 10) & nota $>6$ & 1.85 & 0.29 & 6.32 & 0.00 & 6.35 \\
\hline Avaliação HGPE Quintão (0 a 10) & nota $>6$ & -0.31 & 0.30 & -1.02 & 0.31 & 0.73 \\
\hline Avaliação HGPE Jô (0 a 10) & nota $>6$ & -0.95 & 0.32 & -3.00 & 0.00 & 0.39 \\
\hline Satisfação com a vida pessoal & Muito satisfeito & 0.14 & 0.22 & 0.65 & 0.52 & 1.15 \\
\hline
\end{tabular}

27 A colinearidade ocorre quando temos duas ou mais variáveis independentes se relacionando através de uma combinação linear entre elas. Quando a combinação é perfeita, a estimação não é possível, pois a matriz de valores não é full rank e, logo, não permite o cálculo matricial.

28 Do inglês Independence of Irrelevant Alternatives.

29 Na seção referente à análise dos resultados são apresentados os resultados dos modelos finais para os dois turnos, considerando todas as variáveis. Contudo, foram também testados modelos "com" e "sem" as variáveis de campanha ("exposição ao HGPE" e "avaliações do HGPE"), que se mostraram essenciais para explicar o voto em Belo Horizonte. Ao acrescentar a "exposição ao HGPE" ao modelo, essa variável torna-se significativa em todas as categorias, além de aumentar o pseudo R2. Quando acrescentamos as "avaliações de campanha", a exposição é controlada e, no modelo final, as avaliações mostraram-se bastante significativas e com forte capacidade preditiva. Na análise dos resultados foram interpretados os coeficientes do modelo final. 


\begin{tabular}{|c|c|c|c|c|c|c|}
\hline Avaliação da economia do país & Boa/ótima & 0.36 & 0.25 & 1.42 & 0.16 & 1.44 \\
\hline Autolocalização & Direita & 0.75 & 0.29 & 2.56 & 0.01 & 2.12 \\
\hline Autolocalização & Esquerda & -0.68 & 0.33 & -2.07 & 0.04 & 0.51 \\
\hline Aprovação governo presidente Lula & bom/ótimo & 0.37 & 0.25 & 1.50 & 0.13 & 1.45 \\
\hline Aprovação governador Aécio - PSDB & bom/ótimo & 0.60 & 0.32 & 1.86 & 0.05 & 1.82 \\
\hline Aprovação prefeito Pimentel - PT & bom/ótimo & 0.51 & 0.29 & 1.80 & 0.07 & 1.67 \\
\hline Constante & - & -1.46 & 0.38 & -3.82 & 0.00 & 0.23 \\
\hline \multicolumn{7}{|l|}{ Jô Moraes (PC do B) } \\
\hline Gênero & Masculino & -0.56 & 0.30 & -1.86 & 0.05 & 0.57 \\
\hline Idade & Jovem (16 a 24 anos) & -0.22 & 0.40 & -0.55 & 0.58 & 0.80 \\
\hline Renda familiar & Mais de 5 SM & 0.48 & 0.33 & 1.45 & 0.15 & 1.62 \\
\hline Escolaridade & Ensino médio e superior & 0.77 & 0.34 & 2.26 & 0.02 & 2.15 \\
\hline Preferência partidária & PMDB & 0.71 & 0.72 & 0.99 & 0.32 & 2.03 \\
\hline Preferência partidária & PT & 0.72 & 0.34 & 2.13 & 0.03 & 2.05 \\
\hline Preferência partidária & PSDB & 0.03 & 0.13 & 0.24 & 0.81 & 1.03 \\
\hline Exposição ao HGPE & Às vezes/todo dia & 0.38 & 0.33 & 1.15 & 0.25 & 1.46 \\
\hline Avaliação HGPE Lacerda (0 a 10) & nota $>6$ & -1.11 & 0.41 & -2.70 & 0.01 & 0.33 \\
\hline Avaliação HGPE Quintão (0 a 10) & nota $>6$ & -0.21 & 0.40 & -0.53 & 0.60 & 0.81 \\
\hline Avaliação HGPE Jô (0 a 10) & nota $>6$ & 2.13 & 0.38 & 5.61 & 0.00 & 8.42 \\
\hline Satisfação com a vida pessoal & Muito satisfeito & 0.19 & 0.30 & 0.63 & 0.53 & 1.21 \\
\hline Aval. economia do país & Boa/ótima & 1.09 & 0.33 & 3.35 & 0.00 & 2.98 \\
\hline Autolocalização & Direita & -0.07 & 0.43 & -0.15 & 0.88 & 0.94 \\
\hline Autolocalização & Esquerda & -0.01 & 0.39 & -0.04 & 0.97 & 0.99 \\
\hline Aprovação governo presidente Lula & bom/ótimo & 0.31 & 0.35 & 0.89 & 0.37 & 1.36 \\
\hline Aprovação governador Aécio - PSDB & bom/ótimo & 0.02 & 0.40 & 0.05 & 0.96 & 1.02 \\
\hline Aprovação prefeito Pimentel - PT & bom/ótimo & 0.18 & 0.36 & 0.51 & 0.61 & 1.20 \\
\hline Constante & - & -2.58 & 0.53 & -4.88 & 0.00 & 0.08 \\
\hline \multicolumn{7}{|l|}{ Leonardo Quintão (PMDB) } \\
\hline Gênero & Masculino & -0.41 & 0.27 & -1.53 & 0.13 & 0.66 \\
\hline Idade & Jovem (16 a 24 anos) & 0.14 & 0.32 & 0.45 & 0.66 & 1.16 \\
\hline Renda familiar & Mais de $5 \mathrm{SM}$ & 0.42 & 0.31 & 1.35 & 0.18 & 1.52 \\
\hline Escolaridade & Ensino médio e superior & 0.73 & 0.31 & 2.40 & 0.02 & 2.08 \\
\hline Preferência partidária & PMDB & 1.99 & 0.51 & 3.87 & 0.00 & 7.29 \\
\hline Preferência partidária & PT & 0.59 & 0.31 & 1.88 & 0.06 & 1.81 \\
\hline Preferência partidária & PSDB & -0.01 & 0.11 & -0.13 & 0.89 & 0.99 \\
\hline Exposição ao HGPE & Às vezes/todo dia & 0.25 & 0.30 & 0.83 & 0.41 & 1.28 \\
\hline Avaliação HGPE Lacerda (0 a 10) & nota $>6$ & -0.61 & 0.36 & -1.72 & 0.09 & 0.54 \\
\hline Avaliação HGPE Quintão (0 a 10) & nota $>6$ & 2.17 & 0.35 & 6.25 & 0.00 & 8.73 \\
\hline Avaliação HGPE Jô (0 a 10) & nota $>6$ & -0.61 & 0.37 & -1.66 & 0.10 & 0.54 \\
\hline Satisfação com a vida pessoal & Muito satisfeito & 0.42 & 0.27 & 1.52 & 0.13 & 1.51 \\
\hline Avaliação economia do país & Boa/ótima & 0.28 & 0.31 & 0.90 & 0.37 & 1.32 \\
\hline Autolocalização & Direita & 0.33 & 0.36 & 0.91 & 0.36 & 1.39 \\
\hline Autolocalização & Esquerda & -0.13 & 0.37 & -0.34 & 0.73 & 0.88 \\
\hline Aprovação governo presidente Lula & bom/ótimo & -0.01 & 0.29 & -0.03 & 0.98 & 0.99 \\
\hline Aprovação governador Aécio - PSDB & bom/ótimo & 0.49 & 0.39 & 1.26 & 0.21 & 1.64 \\
\hline Aprovação prefeito Pimentel - PT & bom/ótimo & -0.04 & 0.33 & -0.12 & 0.91 & 0.96 \\
\hline Constante & - & -2.39 & 0.47 & -5.04 & 0.00 & 0.09 \\
\hline \multicolumn{7}{|l|}{ Obs. $=717$} \\
\hline \multicolumn{7}{|l|}{ Chi2 $=421.08$ (sig. $<0.001)$} \\
\hline \multicolumn{7}{|l|}{ Pseudo R2 de McFadden= 0.2325} \\
\hline
\end{tabular}

Obs.: respectivas categorias de referência das variáveis dummy: gênero feminino; mais de 24 anos; renda menor que 5 salários mínimos; ensino até a 8 a série; nenhum ou outros; nenhum ou outros; nenhum ou outros, nunca/raramente; caso contrário; caso contrário; caso contrário; nada/ pouco/ + ou - satisfeito; péssima/ruim/regular; centro ou nenhum; centro ou nenhum; caso contrário; caso contrário; caso contrário. 


\section{Márcio Lacerda (PSB)}

Lacerda, então candidato do PSB, era considerado sui generis, por ser um bem-sucedido empresário pertencente a um partido de centro-esquerda de pequena penetração eleitoral na cidade, mas apoiado por uma aliança regional informal entre o PSDB, do governador Aécio Neves, e o PT, do prefeito Fernando Pimentel. A aliança não pôde ser formalizada pela discordância no âmbito das diretivas nacionais dos partidos. Essa formação, o apoio e a ascensão meteórica de Lacerda nas pesquisas de intenção depois de duas semanas de campanha televisiva trazem em si vários efeitos diversos que poderiam influenciar a identificação com o candidato. Nosso modelo reflete essa diversidade de efeitos e traz alguma luz sobre os fatores que mais determinaram a escolha do candidato.

A análise indica que a escolha de Márcio Lacerda foi determinada por uma renda familiar mais alta, pela avaliação positiva da campanha do candidato, pela resistência à campanha da oponente Jô Morais (única candidata a apresentar-se nitidamente como de oposição), pela autolocalização à direita e uma resistência dos eleitores autolocalizados à esquerda. Agregada a esses fatores, a intenção de voto em Lacerda foi também determinada pela avaliação positiva do governo de Aécio Neves, apoiador do candidato.

Como se pode observar pelas análises dos odds da comparação da escolha entre Lacerda e a opção por nenhum candidato, o indivíduo com renda familiar maior que 5 salários mínimos apresenta 2,28 vezes mais chances de votar em Lacerda do que aquele com até 5 salários. Aqueles que se identificam como direita têm 2,12 vezes mais chances de escolher Lacerda. A força explicativa dessa variável de autolocalização fica maior quando se observa que, entre os eleitores autodeclarados à esquerda, as chances de votar em Lacerda reduzem-se em 49\%. Os que avaliaram muito positivamente a propaganda do HGPE do peessebista têm 6,35 vezes mais chances de escolhê-lo. Já aqueles que avaliaram positivamente a campanha de Jô Moraes têm 61\% menos chances de escolher Lacerda. Finalmente, os eleitores que estão muito satisfeitos com o governo do estado tiveram $82 \%$ mais chances de optar por Lacerda.

\section{Leonardo Quintão (PMDB)}

O candidato do PMDB foi destacado como aquele que correu por fora na corrida. O modelo já indica a oposição e o embate entre Jô Moraes e Márcio Lacerda candidatos que disparam no início da campanha. A análise indica que Quintão foi beneficiado pelos partidários da tradicional legenda do PMDB, por uma escolaridade maior e pela sua campanha eleitoral no HGPE.

Os que apresentam preferência partidária pelo PMDB têm 7,29 vezes mais chances de escolher o candidato; aqueles com escolaridade a partir do en- sino médio têm o dobro de chances de escolher o candidato. Em relação aos eleitores que avaliam bem sua propaganda no HGPE, esses têm 8,73 vezes mais chances de se decidirem pelo candidato.

\section{Jô Moraes (PC do B)}

A deputada federal do PC do B já exibia uma longa trajetória política na esquerda em Minas Gerais. Sua imagem difundida permitiu a liderança inicial na corrida eleitoral. Contudo, seu declínio foi rápido. A análise sugere que a escolha na candidata foi determinada por indivíduos do sexo feminino, de alta escolaridade, que se identificavam com o PT e que apreciaram a sua propaganda no HGPE, que não avaliaram bem o HGPE do oponente do PSB e que avaliam bem a situação econômica do país.

As mulheres têm um pouco mais que o dobro de chances de escolherem a candidata em relação aos homens. Os de escolaridade acima do $1^{\circ}$ grau têm 2,15 vezes mais chances de escolher Jô Moraes do que aqueles com educação até a $8^{\mathrm{a}}$ série. Jô Morais recebeu apoio de entidades de professores, como o Sindicato dos Professores de Minas Gerais (Sinpro-MG), e era percebida como uma candidata vinculada à intelectualidade de esquerda da cidade. Talvez por sua inserção em movimentos sociais, os eleitores que manifestavam preferência pelo PT tinham o dobro de chances de escolher a candidata do partido comunista. A avaliação positiva do HGPE de Lacerda diminui as chances de voto na candidata em $67 \%$ em relação aos que não avaliam bem Lacerda. A boa avaliação no HGPE da candidata aumenta a chance de votar nela em 8,42 vezes. Os que avaliam a situação econômica do país positivamente têm três vezes mais chances de votar em Jô Moraes.

No segundo turno é enfatizado o elemento conjuntural da propaganda política eleitoral, e interessantes elementos são captados a partir da influência partidária. Lacerda, mais uma vez, contou com eleitores de maior renda, entre os quais houve 2,13 vezes mais de chances de o indivíduo escolhê-lo do que o eleitor de renda menor. $\mathrm{O}$ candidato contou ainda com partidários do PT e PSDB, com ênfase para os eleitores tucanos, entre os quais houve 3,24 vezes mais chances de escolher o candidato e três vezes mais chances no caso dos petistas. A propaganda política, elemento importante em uma eleição bastante disputada - como na ocorrida na cidade de Belo Horizonte -, mostra que havia 6,73 vezes mais chances de votar no candidato entre aqueles que avaliaram bem seu horário político.

Leonardo Quintão também contou com partidários do $\mathrm{PT}$, mas menos que seu oponente. De maior relevância foi a identificação com o PMDB; o indivíduo com preferência por esse partido apresentou 3,93 vezes mais chance de votar em Quintão. Os que avaliaram bem a campanha do peemedebista tinham 12,63 vezes mais chances de escolhê-lo. 
Tabela 6. Parâmetros do Modelo de Regressão Logística Multinomial de Intenção de Voto estimulada - ( $2^{\circ}$ turno)

\begin{tabular}{|c|c|c|c|c|c|c|}
\hline Variáveis & Categorias Dummy & Coef.(B) & Erro Padrão & Wald (z) & Prob. $>|z|$ & Odds Ratio \\
\hline \multicolumn{7}{|l|}{ Márcio Lacerda (PSB) } \\
\hline Gênero & Masculino & -0.03 & 0.23 & -0.14 & 0.89 & 0.97 \\
\hline Idade & Jovem (16 a 24 anos) & -0.17 & 0.31 & -0.56 & 0.57 & 0.84 \\
\hline Renda familiar & Mais de 5 SM & 0.76 & 0.27 & 2.84 & 0.01 & 2.13 \\
\hline Escolaridade & Ensino médio e superior & -0.39 & 0.27 & -1.45 & 0.15 & 0.68 \\
\hline Preferência partidária & PMDB & 0.50 & 0.47 & 1.05 & 0.29 & 1.65 \\
\hline Preferência partidária & PT & 1.10 & 0.32 & 3.45 & 0.00 & 3.01 \\
\hline Preferência partidária & PSDB & 1.18 & 0.52 & 2.26 & 0.02 & 3.24 \\
\hline Exposição ao HGPE & Às vezes/todo dia & -0.02 & 0.25 & -0.07 & 0.94 & 0.98 \\
\hline Avaliação HGPE Lacerda (0 a 10) & nota $>6$ & 1.91 & 0.30 & 6.44 & 0.00 & 6.73 \\
\hline Avaliação HGPE Quintão (0 a 10) & nota $>6$ & -0.63 & 0.34 & -1.87 & 0.06 & 0.53 \\
\hline Aprovação governo presidente Lula & bom/ótimo & 0.04 & 0.25 & 0.17 & 0.86 & 1.04 \\
\hline Aprovação governador Aécio - PSDB & bom/ótimo & 0.37 & 0.31 & 1.17 & 0.24 & 1.45 \\
\hline Aprovação prefeito Pimentel - PT & bom/ótimo & 0.43 & 0.30 & 1.43 & 0.15 & 1.53 \\
\hline Constante & - & -0.45 & 0.35 & -1.29 & 0.20 & 0.64 \\
\hline \multicolumn{7}{|l|}{ Leonardo Quintão (PMDB) } \\
\hline Gênero & Masculino & -0.11 & 0.24 & -0.44 & 0.66 & 0.90 \\
\hline Idade & Jovem (16 a 24 anos) & 0.45 & 0.31 & 1.44 & 0.15 & 1.57 \\
\hline Renda familiar & Mais de $5 \mathrm{SM}$ & 0.00 & 0.29 & -0.01 & 1.00 & 1.00 \\
\hline Escolaridade & Ensino médio e superior & -0.30 & 0.28 & -1.07 & 0.28 & 0.74 \\
\hline Preferência partidária & PMDB & 1.37 & 0.46 & 2.99 & 0.00 & 3.93 \\
\hline Preferência partidária & PT & 0.84 & 0.34 & 2.49 & 0.01 & 2.31 \\
\hline Preferência partidária & PSDB & 0.27 & 0.58 & 0.46 & 0.64 & 1.31 \\
\hline Exposição ao HGPE & Às vezes/todo dia & -0.17 & 0.27 & -0.63 & 0.53 & 0.85 \\
\hline Avaliação HGPE Lacerda (0 a 10) & nota $>6$ & -0.40 & 0.33 & -1.19 & 0.23 & 0.67 \\
\hline Avaliação HGPE Quintão (0 a 10) & nota $>6$ & 2.54 & 0.32 & 7.87 & 0.00 & 12.63 \\
\hline Aprovação governo presidente Lula & bom/ótimo & 0.29 & 0.27 & 1.09 & 0.27 & 1.34 \\
\hline Aprovação governador Aécio - PSDB & bom/ótimo & 0.04 & 0.32 & 0.11 & 0.91 & 1.04 \\
\hline Aprovação prefeito Pimentel - PT & bom/ótimo & -0.07 & 0.31 & -0.24 & 0.81 & 0.93 \\
\hline Constante & - & -0.31 & 0.36 & -0.87 & 0.39 & 0.73 \\
\hline \multicolumn{7}{|l|}{ Obs. $=751$} \\
\hline \multicolumn{7}{|l|}{ Chi2 $=401.92($ sig. $<0.001)$} \\
\hline Pseudo R2 de McFadden= 0.2603 & & & & & & \\
\hline
\end{tabular}

Obs.: respectivas categorias de referência das variáveis dummy: gênero feminino; mais de 24 anos; renda menor que 5 salários mínimos; ensino até a $8^{a}$ série; outros ou nenhum; outros ou nenhum; outros ou nenhum; nunca/raramente; caso contrário; caso contrário; caso contrário; caso contrário; caso contrário.

\section{VI - Conclusões}

Uma primeira questão seria a de observar se efetivamente houve interesse pelas eleições. Uma das razões importantes para o voto seria a conexão entre as propostas dos partidos/candidatos e aquelas propostas defendidas pelos eleitores. Assim, quando a eleição oferecesse um cardápio de candidatos distintos, o eleitor teria a possibilidade de selecionar entre alternativas reais e seria levado a uma maior participação. Em Belo Horizonte, observa-se que, às vésperas do segundo turno, cerca de $47 \%$ dos eleitores declararam que se interessam pouco ou nada por política. Entretanto, apesar desse desinteresse por parte dos eleitores e dos discursos semelhantes enunciados pelos partidos - basta recordar que não houve o típico posicionamento de "opositor" entre as duas principais candidaturas -, os níveis de abstenção nas eleições municipais de 2004 e 2008 se aproximaram bastante, ficando na faixa de $16 \%$.

A teoria satisfacionista espera que votar retrospectivamente faça sentido para o eleitor. Por isso, a satisfação com a administração seria central para a decisão do eleitor, que vota julgando as ações dos governantes: se as coisas estão bem, o eleitor escolhe o candidato ou partido do governo; se estão mal, elege a oposição. Todavia, de um modo geral, os governos municipal, estadual e federal estavam bem posicionados. Essa ava- 
liação positiva do desempenho dos mandatários incentivou a campanha de Quintão (PMDB) a utilizar uma estratégia de se associar aos governantes e de projetar uma retórica para o futuro. A crítica contundente ao governo municipal poderia resultar quase certamente na derrota da sua candidatura. Apesar dos esforços de Quintão, a campanha de Lacerda conseguiu apresentá-lo como o candidato do continuísmo e, com isto, o candidato agregou parte dos eleitores satisfeitos com a administração do governador Aécio Neves (PSDB).

A complexidade no processo de tomada de decisão do voto pôde ser confirmada, pois o modelo aqui apresentando expôs que são muitos os elementos utilizados para o cálculo e que atuam sobre o voto; sobretudo emergiu a importância de elementos de curto prazo, ao qual o eleitor e seu voto são sensíveis: a campanha política, indicada pela exposição e pela avaliação dos programas do HGPE dos candidatos.

Em relação à avaliação dos programas eleitorais, destaca-se o embate entre Jô Moraes, que se apresentava em seus escassos minutos como oposicionista a Lacerda. A avaliação positiva do programa televisivo de um desses dois candidatos diminuía a chance de voto no outro. O efeito da avaliação do HGPE é intensificado no segundo turno, especialmente para o candidato do PMDB, que adotou uma estratégia de propaganda mais ativa no sentido de combater o oponente e que privilegiava uma aproximação mais direta com o eleitor. As variáveis de avaliação da propaganda se mostraram muito importantes também para captar os efeitos menos objetivos da campanha e que envolvem o elemento psicológico na disputa.

De forma comparativa com outros conjuntos de variáveis, como a autodefinição do eleitor no espectro direita e esquerda e os índices de avaliação das gestões governamentais nos três níveis (governo Lula, governo Aécio e governo Pimentel), foi a avaliação dos programas do HGPE um dos elementos mais relevantes para explicar as chances de voto para os candidatos, tanto no primeiro quanto no segundo turno da eleição de 2008 em Belo Horizonte. Isso pode ser compreendido, uma vez que todos os candidatos analisados se afirmaram dentro de uma retórica de situação, não buscando a polarização do eleitorado nem se situando como contra ou a favor do status quo. Ao invés de se ofertarem aos eleitores como opositores, os principais concorrentes tentaram uma persuasão no sentido de legitimar um discurso da continuidade e dos ganhos das gestões até então em curso.

Com seus mandatários bem avaliados, PT e PSDB formaram uma aliança, cujo foco de campanha não os diferenciava. O efeito dessa estratégia pode ter sido a alta volatilidade observada nas intenções de voto. Teoricamente, uma das razões para explicar a volatilidade poderia ser encontrada na baixa identidade com os partidos políticos. Contudo, grande parte do eleitorado de Belo Horizonte tem preferência por algum partido. Todavia, não se sabe a intensidade dessa preferência - se fraca, regular ou forte. Assim, ao propor uma aliança com o PSDB, o PT pode ter fragilizado a intensidade da preferência de seus eleitores, pois de acordo com estudos (Samuels, 2004; Telles, 2008), a identidade petista pode ser explicada, sobretudo, por uma avaliação negativa do governo do ex-presidente Fernando Henrique Cardoso (PSDB). Ao propor uma coalizão com esse partido, os eleitores reagiram de modo errático e ficaram mais expostos aos argumentos da campanha.

Notou-se que o personalismo foi elemento central na propaganda veiculada na televisão no primeiro turno. O partido político permaneceu como adereço e apenas passou a emergir nas campanhas a partir do segundo turno. O PT - partido que apoiava Lacerda - passa a ser apresentado nos programas para fornecer confiança ao eleitor. Tratou-se de usar a sigla em nome de um candidato com atuação nos espaços institucionais (Lacerda) versus um candidato "populista" e descolado das instituições (Quintão). O surgimento dos partidos nas campanhas ativou o voto baseado na identidade partidária, como demonstrado nos resultados do modelo econométrico, sobretudo para o segundo turno.

Apesar de os partidos não terem sido centrais nas campanhas no primeiro turno e de ter sido observado, por meio dos dados da pesquisa, o fenômeno da migração do voto de petistas para Jô Moraes e Quintão, a preferência por partidos fez alguma diferença e teve efeito sobre o voto, tanto no segmento de eleitores "tucanos" quanto de petistas e peemedebistas. Todavia, as identidades com o PSDB e com o PMDB tiveram mais capacidade preditiva do voto do que o petismo, que se dividiu. O fato de os eleitores petistas não terem seguido à risca a indicação de suas lideranças municipais pode ter sido um "castigo" deles em relação à estratégia do partido, que contrariou as supostas razões para que o eleitor se identificasse com o PT e propôs uma aliança com o PSDB.

Em função das estratégias de campanhas, dificilmente a identidade partidária poderia vir a funcionar como o principal atalho para a decisão de voto. A personalização dos discursos e o apartidarismo das campanhas foram as estratégias amplamente empregadas, inclusive pelo grupo de centro-esquerda. A decorrência dessa política centrada nos candidatos é a redução da confiança nas instituições representativas como as mais eficazes para organizar os processos políticos, com a consequente entrada de candidatos outsiders.

As campanhas na televisão contam com a vantagem de oferecer mensagens a um número expressivo de votantes de forma simultânea. Para chamar a atenção dos eleitores, em sua maioria desinteressada pela política, os partidos, muitas vezes, se adequam ao contorno ao qual o cidadão está habituado. Mas fazem isso atribuindo à campanha as mesmas normas de qualquer 
espetáculo ou apenas adaptam sua linguagem ao meio televisivo? Como já discutimos a respeito da racionalidade, o eleitor tem informações fragmentadas, mas nem por isso deixa de tomar decisões racionais, decisões essas que não são alienadas ou apenas voltadas ao espetáculo, senão usando-as também como ajuda. Os eleitores utilizam o HGPE como mais um subsídio e espaço para conhecer o candidato e suas propostas. $\mathrm{Na}$ visão do cidadão comum, o horário eleitoral é, para além do "circo", uma síntese informativa acerca das candidaturas.

Mas, para 90\% dos eleitores de Belo Horizonte, a maioria dos políticos eleitos não cumpre as promessas que faz durante a campanha, o que nos leva a refletir que não é apenas a TV a responsável pela situação de desencanto com a política: os partidos, ao se ajustarem à sociedade do espetáculo, deixam de realizar sua função de expressar interesses e apresentar programas e se convertem, sobretudo, em máquinas de comunicação, esvaziando o sentido substantivo da representação política. No entanto, há mudanças sutis que podem ser observadas: a literatura espera que o voto personalizado e decidido a partir das avaliações conjunturais e mais suscetíveis à influência das campanhas deve ser encontrado na maioria do eleitorado brasileiro. Em Belo Horizonte, apesar da influência dos fatores conjunturais, os dados coletados pelos surveys nos informaram que, para a maioria dos eleitores, a proposta e o programa do candidato são a principal orientação para a sua decisão de voto. Os eleitores entrevistados asseveraram que votam retrospectivamente, ou seja, avaliam o passado do candidato, julgando as ações do político, antes de definir se darão a ele uma chance de ocupar um cargo de representação. Todavia, durante a campanha, os eleitores foram mais expostos às candidaturas individuais e coalizões, o que tornou pouco provável o reforço dos vínculos entre partidos e eleitores.

O calendário eleitoral, as eleições proporcionais com listas abertas e a possibilidade de coligações afetam as estratégias dos partidos, os resultados das eleições e a possibilidade de o mandatário municipal governar com maioria de apoio na Câmara Municipal. Uma vasta literatura se dedicou a demonstrar que o uso da lista aberta gera a personalização das estratégias de campanha, com a consequente valorização dos atributos dos candidatos sobre as virtudes dos partidos políticos. Assim, nesses sistemas, as atitudes mais racio- nais dos candidatos para vencer as eleições seriam as de ressaltar as suas qualidades individuais, manter seus eleitores em torno de uma rede de fidelidades pessoais e utilizar os recursos do pork barrel. Na medida em que o candidato presume que o seu sucesso em eleições seja decorrente do fato de ser uma pessoa conhecida, a sua tendência seria a de personalizar a disputa e fazer uma campanha centrada em suas qualidades pessoais; mas, se a legenda do partido transmitir confiança, a opção seria a de acentuar o uso do partido, associando sua imagem ao capital construído pela organização.

A despeito dessas estratégias personalistas nessa campanha municipal, observa-se, por outros dados da pesquisa realizada, que a preocupação com o programa do candidato começa a surgir no momento da decisão de voto, mas ainda permanecem arestas a serem analisadas, como a de que $55 \%$ dos eleitores de Belo Horizonte terem afirmado que conhecem alguém que poderia dar o seu voto em troca de vantagens pessoais. Isso significa que o clientelismo ainda permanece como um importante componente da política local. Tal constatação demonstra a necessidade dos políticos em comprometerem-se mais com a cidadania e reforçarem em suas campanhas o programa do partido, suas ideologias e seus propósitos, contribuindo assim com a qualidade da representação e reduzindo a chance de eleição de candidatos não comprometidos com os valores democráticos.

Ao analisar a articulação entre informação e decisão de voto, o pocketbook voting supõe que o eleitor médio define seu voto a partir da percepção que tem sobre sua situação econômica e pessoal. Em relação a essa teoria, pode-se argumentar que os dados demonstraram que o voto não é um reflexo mecânico da situação econômica e pessoal do eleitor e, eventualmente, outros aspectos podem ser ponderados no cálculo. Os eleitores podem distinguir seus problemas individuais daqueles que são provocados pelo governo; podem observar as diferentes esferas de poder e responsabilizar distintos níveis do governo pelas dificuldades enfrentadas; podem ainda separar sua situação atual de suas perspectivas sobre seu futuro. Assim, o conjunto de fatores avaliados comprova que o caminho percorrido até o depósito do voto nas urnas é bastante complexo: o discernimento sobre a divisão de responsabilidades entre as esferas de governo, o balanço entre o passado e os benefícios do futuro, entre outros, podem interferir na decisão do voto.

\section{Referências}

ALBUQUERQUE, Afonso de. A batalha da presidência: o horário de propaganda eleitoral na campanha de 1989. Rio de Janeiro, 1996. Tese (Doutorado em Comunicação) Escola de Comunicação da Universidade Federal do Rio de Janeiro. Aqui você vê a verdade na tevê. A propaganda política na televisão. Niterói: Universidade Federal Fluminense-MCII, 1999. p. 157-186. 
ALMEIDA, Alberto. Ideologia e comportamento eleitoral: evidências de que a ideologia não é importante para explicar o voto. In: XXV ENCONTRO ANUAL DA ANPOCS, Caxambu, 2001.

AMEMIYA, Takeshi. Qualitative response models: a survey. Journal of Economic Literature, n. 19, p. 1483-536, 1981. ARROW, Kenneth. Social choice and individual values. New York: John Wiley \& Sons, 1951.

BELSLEY, David; KUH, Edwin; WELSCH, Roy. Regression diagnostics: identifying influential data and sources of collinearity. Wiley Inter-science, 2004.

BRAGA, Maria do Socorro; KINZO, D’Alva. Eleitores e representação partidária no Brasil. São Paulo: Humanitas, 2007. BORBA, Julian. Cultura política, ideologia e comportamento eleitoral: alguns apontamentos sobre o caso brasileiro. Opinião Pública, Campinas, v. 11, n.1, p. 147-168, 2005.

CAMPBELL, A. et al. The American voter. New York: Wiley, 1960.

CARREIRÃO, Yan. Identificação ideológica e voto para presidente. Opinião Pública, n. 8, p.54-79, 2002.

A decisão de voto nas eleições presidenciais brasileiras. Rio de Janeiro/Florianópolis: Editora da FGV/Edufsc, 2002

Identificação ideológica, partidos e voto na eleição presidencial de 2006. Opinião Pública, vol. 13, n. 2, p.307-339, nov. 2007.

2007. Relevant factors for the voting decision in the 2002 presidential elections: an analysis of the Eseb (Brazilian Electoral Studies) Data. Brazilian Political Science Review, n. 1, p.70-101, 2007.

CASTRO, Mônica M.M. Sujeito e estrutura no comportamento eleitoral. Revista Brasileira de Ciências Sociais, n. 20, São Paulo, Anpocs, 1992.

Determinantes do comportamento eleitoral - a centralidade da sofisticação política. Rio de Janeiro, 1994. Tese (Doutorado) - Iuperj.

CONVERSE, Philip. The nature of belief systems in mass publics. Ideology and discontent. Ed. David Apter, 1964.

DALTON, Russell. The decline of party identification. In: DAlton, Russel; WATtenBERG, Martin. Parties without partisans: political change in advanced industrial democracies. Oxford: Oxford University Press, 2000. p. 19-36.

DALTON, Russell; MCALLISTER, Ian; WATTENBERG, Martin. The consequences of partisan dealignment. In: DALTON, Russel; WATTENBERG, Martin. Parties without partisans: political change in advanced industrial democracies. Oxford: Oxford University Press, 2000. p. 37-63.

DIAS RIBEIRO, Márcia. Projeção da imagem partidária nas estratégias de campanha na televisão: uma análise do HGPE. 2002. Dados, n. 1 (48), p. 149-187, 2005.

DOWNS, Anthony. Uma teoria econômica da democracia. São Paulo: Edusp, 1998 [1957].

FIGUEIREDO, Marcus. A decisão do voto - democracia e racionalidade. São Paulo: Sumaré/Anpocs, 1991. et al. Estratégias de persuasão em eleições majoritárias: uma proposta metodológica para o estudo da propaganda eleitoral. In: FIGUEIREDO, Rubens et. al. (Org.). Marketing político e persuasão eleitoral. São Paulo: Fundação Konrad-Adenauer, 2000.

; ALDÉ, Alessandra. Intenção de voto e propaganda política: efeitos e gramáticas da propaganda eleitoral. In: $12^{\circ}$ ENCONTRO ANUAL DA COMPÓS, Recife, junho de 2003.

FIGUEIREDO, Rubens; COUTINHO, Ciro. A eleição de 2002. Opinião Pública, n. 2, p. 93-117, outubro de 2003.

FIORINA, Morris. Retrospective voting in American national elections. New Haven/London: Yale University Press, 1981.

GREENE, William. Econometric analysis. 4 ed. New Jersey: Prentice Hall, 2000.

HAUSMAN, Jerry; McFADDEN, Daniel. Specification tests for the Multinomial Logit Model. Econometrica, v. 52, n. 5, 1984, p. 1219-1240.

HIRSCHMAN, Albert. Exit, voice and loyalty. Cambridge, Massachusetts: Harvard University Press, 1970.

HOLBROOK, Thomas M. Do campaigns matter? Sage $\mathrm{Pu}-$ blications Inc., 1996.

HOTELliNG, Harold. Stability in Competition. Economic Journal, n. 39, p. 41-57, 1929.

Informe Latinobarómetro 2008. Disponível em: www.latinobarometro.org/docs/INFORME_ LATINOBAROMETRO_2008.pdf.

IYENGAR, Shanto; SIMON, Adam. New perspectives and evidence on political communication and campaign effects. Annu. Rev. Psychol., n. 51, p. 149-169, 2000.

JORGE, Wladimyr. L. Eleição presidencial de 1994 e os meios de comunicação de massa - uma análise da propaganda eleitoral gratuita de Fernando Henrique Cardoso e Luiz Inácio Lula da Silva na televisão. Rio de Janeiro, 1995. Dissertação (Mestrado em Ciências Políticas) - Iuperj.

KUSCHNIR, Karina. Eleições e representação no Rio de Janeiro. Rio de Janeiro: Relume-Dumará, 2000.

LAMOUNIER, Bolívar; CARDOSO, Fernando H. Os partidos e as eleições no Brasil. Rio de Janeiro: Paz e Terra, 1975.

LAZARSFELD, Paul; BERELSON, Bernard; GAUDET Hazel. The people's choice. New York: Columbia University Press, 1948.

LIMA, Venício A. de. Mídia: teoria e política. São Paulo: Editora Fundação Perseu Abramo, 2001.

LOURENÇO, Luiz C. Ativação, reforço e cristalização: pistas sobre os efeitos do Horário Gratuito de Propaganda Eleitoral (HGPE) em 1998. In: TELES, H. de S.; LUCAS, J. I. (Org.). Das ruas às urnas: partidos e eleições no Brasil contemporâneo. Editora Universidade Caxias do Sul, 2003.

Abrindo a caixa-preta: da indecisão à escolha. A eleição presidencial de 2002. Rio de Janeiro, 2007. Tese (Doutorado em Ciências Políticas e Sociologia) -Iuperj. LUPIA, Arthur; McCUBBINS, Mathew D. The democratic 
dilemma: can citizens learn what they need to know? New York: Cambridge University Press, 1998.

MADDALA, Gangadharrao S. Limited dependent and qualitative variables in econometrics, cap. 2. Cambridge: Cambridge University, 1983.

MAINWARING, Scott. Sistemas partidários em novas democracias: o caso do Brasil. Rio de Janeiro: Editora FGV, 1999.

MANCINI, Paolo, SWANSON, David. Politics, media and modern democracy: an international study of innovations in electoral campaigning and their consequences. London: Praeger, 1996.

MANIN, Bernard. As metamorfoses do governo representativo. Revista Brasileira de Ciências Sociais, n. 29, p. 5-34, 1995.

MORENO, Alejandro. El votante mexicano. Democracia, actitudes politicas y conducta electoral. Fondo de Cultura Economica, 2003.

MENEGUELLO, Rachel. Electoral behavior in Brazil: the 1994 presidential election. International Social Science Journal, n. 146, 1995.

MIGUEL, Luis Felipe. Discursos cruzados: telenoticiários, HPEG e a construção da agenda eleitoral. Sociologias, Porto Alegre, n. 11, junho de 2004.

NEUMAN, W. Russell. The paradox of mass politics: knowledge and opinion in the American electorate. Cambridge: Harvard University Press, 1986.

NICOLAU, Jairo. An analysis of the 2002 presidential elections using logistic regression. Brazilian Political Science Review, v. 1, n. 1, p. 125-135, 2007.

OLIVEIRA, Luiz A. As estratégias retóricas na construção dos mundos de natureza ficcional da política: um estudo comparativo das campanhas de Belo Horizonte e Salvador na eleição municipal de 2000. Rio de Janeiro, 2004. Tese (Doutorado em Ciências Políticas) - Iuperj.

OLIVEIRA, Cloves L. P. A inevitável visibilidade da cor: estudo comparativo das campanhas de Benedita da Silva e de Celso Pitta às Prefeituras do Rio de Janeiro e São Paulo, nas eleições de 1992 e 1996. Rio de Janeiro, 2007. Tese (Doutorado em Ciências Políticas) - Iuperj.

PALMEIRA, Moacir. Voto: racionalidade ou significado?. Revista Brasileira de Ciências Sociais, n. 20, p. 26-30, 1992.

PALMEIRA, Moacir; GOLDMAN, Márcio. (Org.). Antropologia, voto e representação política. Rio de Janeiro: Contra Capa, 1996.

PALMEIRA, Moacir; HEREDIA, Beatriz, M. A. Les temps de la politique. Études Rurales, n. 131-132, p. 73-87, 1993.
POPKIN, Samuel L. The reasoning voter. Chicago: The Chicago University Press, 1994 [1991].

REIS, Fábio. W.; CASTRO, Mônica M. M. Regiões, classe e ideologia no processo eleitoral brasileiro. Lua Nova, v. 26, p. 81-131, 1992.

REIS, Fábio W. Os partidos e o regime: a lógica do processo eleitoral brasileiro. São Paulo: Símbolo, 1978.

ROCHA NETO, Fenelon Martins. La profesionalización de las campañas electorales en Brasil (1989-2006). 2008. Tese (Doutorado) - Universidad de Salamanca.

RIKER, William H. The strategy of rhetoric. New Haven: Yale University Press, 1996.

RUBIM, Antônio A. (Org.). Mídia e eleições de 1998. Salvador: Facom/UFBA, 2000.

SAMUELS, David. As bases do petismo. Opinião Pública. Campinas, v. X, n. 2, out. 2004, p. 221-241.

A evolução do petismo. Opinião Pública, Campi-

nas, v. 14, n. 2, nov. 2008, p. 302-318.

SILVEIRA, Flávio. A decisão de voto no Brasil. Porto Alegre: EdipucRS, 1998.

SINGER, André. Esquerda e direita no eleitorado brasileiro. São Paulo: Edusp, 2000.

TELLES, Helcimara de S. Estrategias de campaña política: eslogan y retóricas en elecciones para alcalde. América Latina Hoy, Salamanca, n. 51, abril de 2009.

Eleitor volátil, eleitor petista: que samba isso dá em Beagá? In: $6^{\circ}$ ENCONTRO NACIONAL DA ASSOCIAÇÃO BRASILEIRA DE CIÊNCIA POLÍTICA (ABCP), Campinas, Unicamp, jul. 2008(a).

Comportamento eleitoral: o eleitor e seu voto.

In $1^{\circ}$ SIMPÓSIO NACIONAL DE MARKETING POLÍTICO E OPINIÃO PÚBLICA. Belo Horizonte: DCP/ UFMG, nov. 2008(b).

VEIGA, Luciana Fernandes. Em busca de razões para o voto: o uso que o homem comum faz do horário eleitoral. Rio de Janeiro, 2002. Tese (Doutorado em Ciências Políticas) - Iuperj. Os partidos brasileiros na perspectiva do eleitores. Opinião Pública, v. 13, n. 2, p. 340-65, 2007.

VENTURI, Gustavo. A opinião pública diante da crise. Teoria e Debate, v. 66, 2006.

Base de Dados

Pesquisa $A$ decisão de voto em eleições municipais, realizada pela UFMG/Ipespe, Belo Horizonte, setembro/ outubro de 2008. 


\title{
Political parties, campaign, and voting: voter decision-making in municipal elections
}

\begin{abstract}
The election for mayor in the capital of the state of Minas Gerais in 2008 occurred in a complex context, characterized by alternating positions of the leading candidates in the polls and by a controversial, informal alliance between PT and PSDB. This study aims at offering the electoral groups' profiles and at assessing the determinants of the electoral choice in the 2008 mayoral election in Belo Horizonte (MG - Brazil). Making use of a multinomial model of logistic regression, we examine the effects of campaign exposure, party identification and the evaluation of mandates' and economy's performances on the voting decision for mayor. The data were collected by surveys carried out by the Universidade Federal de Minas Gerais and the Instituto de Pesquisas Sociais, Políticas e Econômicas (IPESPE), during the election's first and second rounds.
\end{abstract}

Key words: elections; electoral behavior; party identification; voting.

\section{Partidos, campañas y voto: como el elector decide en las elecciones municipales}

\begin{abstract}
Resumen
La elección para alcalde en la capital de Minas Gerais en 2008 se dio en un contexto complejo, fijado por la alternancia de los candidatos en las pesquisas de intención de voto y por la alianza informal que causó controversias entre PT y PSDB. Ese artículo tiene el objetivo de evaluar los determinantes de la elección para alcalde, presentar el perfil de los grupos de electores y evaluar los determinantes de la elección para alcalde de Belo Horizonte en las elecciones de 2008. Usando un modelo de regresión logística multinomial, examinamos, sobre todo, la influencia de la identidad con los partidos políticos, la evaluación del desempeño de los dirigentes y de la economía y la exposición de los electores a la campaña sobre la decisión del voto para alcalde. Los datos fueron seleccionados a partir de encuestas realizadas por la Universidade Federal de Minas Gerais y el Instituto de Pesquisas Sociais, Políticas e Econômicas (IPESPE), en la primera y segunda vuelta de la elección.
\end{abstract}

Palabras clave: elecciones; comportamiento electoral; identidad partidaria; voto.

Recebimento: 16-02-2009

Aprovação:14-05-2009 
